\title{
Padre Raulino Reitz e as ciências naturais no Brasil
}

\author{
Rogerio F. Guerra ${ }^{1}$ \\ Universidade Federal de Santa Catarina
}

\section{Relatos sobre as riquezas do Brasil}

Iguns exploradores, como Pero Vaz de Caminha, o cronista do descobrimento,
fizeram relatos da biodiversidade brasileira. A carta de Caminha descreve genericamente alguns animais e plantas, mas não restam dúvidas sobre o uso do corante vermelho extraído do urucum (Bixa orellana) e o preto derivado do suco do jenipapo (Genipa americana). Os dois corantes ainda são utilizados pelos índios para adornarem a pele e o processo de extração do urucum é o mesmo de 500 anos atrás. Outros exploradores vieram a seguir e enriqueceram os registros da biodiversidade, como Hans Staden (Duas viagens ao Brasil, 1557) que descreveu a importância da mandioca na alimentação diária dos índios. $O$ desafortunado aventureiro alemão foi aprisionado pelos índios Tupinambás - nove meses de "engorda", pois ele era demasiado magro para ser consumido num ritual antropofágico. As invencionices de Staden foram plagiadas por outros exploradores, de modo que a antropofagia passou a ser vista como prática corriqueira entre os nativos do Novo Mundo.

Os relatos de Andre Thevet (Les singularitez de la France Antarctique, 1550) e Jean de Lery (Histoire d'un voyage faict en la terre du Brésil, 1574) têm importância histórica. Thevet descreveu o modo peculiar de extração do suco de jenipapo pelos índios. Eles mastigavam o fruto e dele extraíam um líquido claro, mas que, ao ser espalhado pelo corpo, se transformava num corante entre negro e azulado. Outra curiosidade foi a descoberta da pacoveira, o nome que os nativos davam à bananeira. Thevet ficou encantado com as propriedades nutricionais e singularidade da planta, pois o fruto era saboroso, nutritivo e abundante; ele podia ser consumido imediatamente ou era cozido e servia de complemento alimentar nas refeições.

A dieta alimentar dos nativos era rica em proteínas de origem animal, complementada por frutas e raízes. Eles não usavam animais para aragem do solo, mas plantavam milho, batata-doce e mandioca; eles ateavam fogo nas matas para limpar o terreno, sulcavam a terra com instrumentos de madeira e lançavam as sementes para o plantio. Os índios consumiam uma ampla variedade de produtos naturais, mas não viviam unicamente num sistema de caça-e-coleta.

${ }^{1}$ Editor de RCH. Professor Titular do Departamento de Psicologia. Departamento de Psicologia/ UFSC, Campus Universitário, 88040-900 Florianópolis, SC (E-mail: rfguerra@cfh.ufsc.br). 
O espírito pragmático deu origem a uma agricultura (circunstancial e pouco eficiente, é verdade) e produziu certos avanços na tecnologia alimentar, como a farinha de mandioca e o processo de desidratação da carne, o moquém. A mandioca era descascada e ralada com o auxílio de pedras, conchas e dentes ou ossos de animais; a raspa era espremida vigorosamente para remover o suco tóxico. O produto era levado aquecido em fogo brando, enquanto as $\mathrm{cu}$ nhãs remexiam as panelas para evitar a formação de bolos e aquecimento desigual da farinha. O resultado final era uma farinha alvíssima que servia de base para bolinhos, pirões e tapiocas ou era consumida pura. A farinha de mandioca era facilmente transportável, mantinha o sabor e a qualidade por um longo tempo e atendia às necessidades dos homens em momentos de apuro.

André Thevet não via com bons olhos os costumes da indiada, principalmente no que diz respeito ao suposto apetite por carne humana e completa ignorância das Sagradas Escrituras, mas ficou admirado com o modo de preparo da farinha de mandioca e o cultivo de certas plantas (mandioca, milho, amendoim e banana). A idéia de que nossos ancestrais e os nativos do Novo Mundo viviam em sistema de caça-e-coleta causava desconforto na alma do capuchinho e, com efeito, ele formulou uma curiosa teoria para explicar o uso racional dos recursos da natureza: o Homo sapiens nunca passara pelo sistema oportunístico da caça-e-coleta, pois Adão semeava a terra e conseguia o alimento com o suor de seu rosto. Somente os poetas ou pessoas que não compreenderam os ensinamentos do livro Genesis imaginam que outrora vivíamos num sistema feral - o mau humor era direcionado à obra de Virgilio (70-19 AC). Ao tentar compatibilizar suas observações com a fé religiosa, Thevet explicou o surgimento da agricultura da seguinte forma:

Ora, que os homens universalmente e em toda a Terra tenham vivido como animais selvagens, é antes de tudo uma idéia fantástica do que uma verdade histórica. Só mesmo os poetas é que têm tais idéias, no que são seguidos por aqueles que o imitam. Virgilio expõe esta teoria na primeira de suas Geórgicas, mas eu prefiro acreditar nas Escrituras Sagradas, onde se mencionam os trabalhos agrícolas de Adão e as oferendas que ele fazia a Deus (p. 192). ${ }^{2}$

Os índios desenvolveram engenhosos (e danosos ao meio-ambiente) sistemas de pesca, consumiam larvas de insetos e conheciam razoavelmente o valor nutricional de várias plantas. Eles processavam o alimento e tinham suas beberagens, como o cauim (bebida obtida a partir da fermentação da mandioca ou do milho).

\footnotetext{
${ }^{2}$ Andre Thevet. As singularidades da França Antártica. Belo Horizonte: Editora Itatiaia, 1978.
} 
Outro passatempo eram as fumaças da "herva santa do gentio": os índios enrolavam folhas de petun, acendiam as extremidades e aspiravam por longos períodos a fumaça dos charutões. Thevet descreveu o hábito tabagista dos nossos índios e enviou sementes da planta à França (1550), mas quem levou a fama de descobridor foi Jean Nicot, embaixador francês sediado em Portugal. O alcalóide foi isolado logo a seguir (1571) e o seu nome foi imortalizado no nome da planta (Nicotiana tabacum) e da substância que entorpecia e causava prazer (nicotina).

A fumaça dos charutos servia a propósitos variados, pois o torpor facilitava o acesso ao "mundo dos espíritos" e afugentava os mosquitos; infusões feitas com as folhas da planta eram usadas no combate à verminose, doença muito comum entre os nativos do Novo Mundo. Eles despendiam longo tempo compartilhando a "herva santa", pois as baforadas proporcionavam prazer e curavam a umidade excessiva do cérebro. A alimentação era excessivamente "humida" e de difícil digestão, mas a fumaceira do petun ajudava a purgar a fleuma do estômago e corrigir outros males. Padre Nóbrega tinha sérios problemas estomacais, tinha asma e expelia sangue no catarro e se sentiu tentado a fazer uso da "herva santa", só não fazendo por não concordar com os costumes da indiada. Por seu turno, os cronistas julgavam que aquilo era um presente de Deus e alardearam aos quatro ventos a fabulosa descoberta. A ingênua propaganda foi eficaz, pois o tabagismo se transformou numa praga mundial.

O pai da historiografia brasileira foi Frei Vicente do Salvador (1564-c.1639), autor do primeiro livro sobre a colonização portuguesa. Foi ele o autor da metáfora que informava que os portugueses "caranguejavam as costas do Brasil", na verdade uma crítica severa à negligência dos portugueses por se aventurarem no interior do país. Frei Vicente foi o primeiro a escrever um livro sobre o Brasil numa perspectiva brasileira e isso explica o uso da curiosa metáfora para lançar críticas à política colonialista dos portugueses. Ele não economizou os adjetivos ao descrever as nossas riquezas, como as árvores frondosas que proporcionavam sombra e material para construção das moradias, não esquecendo as folhagens, os palmitos e óleos extraídos das cascas de árvores, os quais substituíam os óleos utilizados nas unções e crismas. A grande variedade de frutos (cajus, maracujás, jenipapos, ananás e melancias) saciava a fome e dava mais sabor à vida. Os relatos do franciscano são repetitivos e redundantes, mas, curiosamente, o estilo é compatível com a luxúria da biodiversidade brasileira.

\section{Os nativos e a biodiversidade}

Os nativos tinham bons conhecimentos sobre as plantas e comportamento dos animais, mas não desenvolveram uma agricultura plena e eficiente e tampouco submetera alguma espécie animal ao processo de domesticação. 
Eles processavam certos alimentos, produziam beberagens e extraíam o suco ou óleo das plantas (jenipapo, coco e dendê); outros produtos apreciados pela indiada eram mel e banha de jacarés ou de cágados, os quais eram utilizados para fins medicinais. Os nativos eram muito seletivos em relação aos ovos (gostavam de ovos de jacarés) e não consumiam leite. A inteligência do noble sauvage também produziu "bombas toxicológicas", obtidas a partir do veneno de sapos, suco da mandioca ou da seiva de cipós ou de certas árvores (curare); o produto era usado nas caçadas ou defesa contra os inimigos.

A idéia que os habitantes do Novo Mundo viviam em harmonia com a natureza merece alguns reparos. Com efeito, os procedimentos adotados nas lavouras de milho e mandioca eram inadequados, pois eles promoviam a derrubada de árvores centenárias ou simplesmente ateavam fogo numa vasta área para suas plantações, mas simplesmente migravam quando exauriam os recursos do local. As pescarias também tinham efeitos catastróficos, pois os índios represavam um trecho do rio e despejavam o veneno extraído da casca de certas árvores (timbó, da família Sapindácea), o que resultava na morte de incontáveis répteis, anfíbios e peixes em estágio larval. O objetivo era a captura de peixes maiores, mas os menores morriam aos borbotões. Padre Anchieta se assustou com a mortandade: cerca de doze mil peixes grandes - a maior parte apodrecia no local, pois a fartura era superior às necessidades da indiada. ${ }^{3}$

Outro tópico que deve ser examinado com cuidado é o grau de sofisticação do conhecimento indígena acerca do valor medicinal das plantas e dos produtos de origem animal. Os simpatizantes da teoria do noble sauvage tendem a valorizar excessivamente esses conhecimentos, mas os naturalistas geralmente têm outras idéias sobre o assunto. Os índios se alimentavam de vários frutos e legumes e conheciam razoavelmente o comportamento dos animais, mas a sua medicina era baseada em beberagens estranhas ou eles recorriam aos pajés para "expulsar os espíritos ruins". Quando alguém era mordido por uma cobra, eles aplicavam banha de jacarés e chifres de cervídeos pulverizados ou chupavam a ferida para extrair o veneno. Para fortalecer o corpo era recomendado o consumo da carne de animais "fortes" ou a ingestão de alimentos "quentes". A terapêutica indígena era intuitiva ou se baseava em crenças religiosas, sem espaço para ensaios ou experimentações.

Os nativos conheciam várias plantas, sabiam detalhes sobre a floração, desenvolvimento e local onde elas eram mais abundantes. Muitas dessas plantas eram utilizadas como ingredientes das beberagens, mas não havia registro dos efeitos e, portanto, a farmacopéia indígena nada mais era que um aglomerado de crendices. A medicina do pajé é baseada na força da persuasão e nas crenças religiosas; ela é mais de natureza espiritual que fisiológica ou, em outras palavras,

${ }_{3}^{3}$ Cartas jesuíticas 3 - Padre José de Anchiéta. Belo Horizonte e São Paulo: Itatiaia e EDUSP, 1988. 
a cura de uma enfermidade é mais resultante da conexão direta do pajé com o mundo dos espíritos que resultante das beberagens propriamente ditas (ver VON MARTIUS, 1939; SANTOS FILHO, 1947). Eis a opinião de dois naturalistas sobre o assunto:

De fato, conhecem os índios muitas ervas e árvores, e sabem diferençá-las por seus próprios nomes; mas isso é sobretudo quando se trata de plantas comestíveis, que sirvam para a tinturaria ou sejam aplicáveis ao uso doméstico. Das plantas medicinais, principalmente remédios (poçanga), eles têm a mais obscura noção, quase sempre supersticiosa, idéia incutida pelos pajés. Em geral, a maioria das plantas, hoje empregadas no Brasil pela medicina, foram achadas pelos primeiros colonos, em particular os paulistas... Conhecem também os silvícolas muitas plantas que são eficazes para certas doenças; entretanto, não têm idéia da dosagem, nem das horas de administração, nem do seu termo. O mais poderoso meio, com que combatem certas doenças, é o jejum, que em certos casos agudos têm eficácia, mas nos crônicos muitas vezes arruína o paciente, levando-o ao extremo (VON SPIX \& VON MARTIUS, 1938; p. 370).

$\mathrm{O}$ uso indiscriminado de plantas e produtos de origem animal é um fenômeno que aproxima a medicina do pajé da medicina popular. $\mathrm{O}$ acesso aos serviços de saúde nem sempre é possível, os custos dos medicamentos convencionais pesam demasiado no orçamento doméstico e, além disso, é crença comum que os "produtos naturais" só trazem benefício ou, quando muito, não interferem negativamente na evolução de uma doença. Entretanto, os efeitos medicinais são facilmente mascarados pela expectativa do usuário e tipo de enfermidade, pois geralmente a terapêutica é aplicada em casos de etiologia inespecífica ou multi-causal (e.g., insônia, depressão, falta de apetite e fraqueza corporal). Existem sérios riscos de contaminações (inseticidas e fungicidas) e, como se tudo isso não bastasse, as propriedades farmacológicas de uma planta são afetadas pela época de colheita e forma de armazenamento. O manuseio descuidado, a umidade e as condições térmicas facilitam a proliferação de fungos e bactérias, os quais adicionam novos e indesejáveis "efeitos terapêuticos" às plantas e ervas (ver GURIB-FAKIM, 2006). Algumas plantas da farmacopéia popular são úteis no combate à verminose e têm propriedades sedativas e antitérmicas, mas muitas plantas supostamente milagrosas não passaram pelos testes laboratoriais e, pior ainda, surtiram perigosos efeitos colaterais. 


\section{As expedições científicas}

A descoberta do Novo Mundo foi resultante dos avanços tecnológicos (bússolas, cartas de navegação e engenharia naval) e do arrojo dos antigos navegadores. Eles estavam penetrando na "zona tórrida", região infestada de serpentes marinhas, tritões e monstros inimagináveis. Os rudes e incultos navegadores temiam o "fim do mundo", pois acreditavam que a terra era plana e, num determinado ponto, o mar despencaria num precipício e engoliria os navios. Eles enfrentavam todo o tipo de privação (fome, sede, motins e doenças) e, ao pisarem nas terras do Novo Mundo, se depararam com um cenário luxuriante, rico em frutas e águas límpidas. A nudez e o aspecto saudável dos índios causaram boa impressão nos esmolambados navegadores, os quais facilmente concluíram que haviam descoberto o Éden terreal.

As antigas expedições científicas duravam meses ou até anos e eram cercadas de percalços e perigos, como encontros com animais de maus-bofes, indiada bravia e todo o tipo de desconforto. As condições higiênicas nem sempre eram adequadas, de modo que uma simples picada de inseto ou leve ferimento podia resultar numa grave infecção. Os exploradores eram homens bem preparados, tinham bom domínio da língua dos índios e muitos eram militares ou pertenciam às ordens religiosas, as quais eram conhecidas por uma disciplina que até ultrapassava os rigores da caserna. Esse era o caso dos loyolistas da Companhia de Jesus.

Outro problema grave eram as doenças tropicais, principalmente malária e infestações parasitárias. Esses problemas eram ocasionados pelo consumo de águas pútridas, ectoparasitos e insetos hematófagos. As tropas do "exército alado" pareciam atuar em esquema de revezamento, pois os ataques ocorriam tanto à noite quando em plena luz do dia; as dolorosas picadas comumente resultavam em ferimentos graves, pois a coceira era insuportável e a sujeira do corpo facilitava as infecções. Os índios minimizavam os ataques dos mosquitos com óleos e tinturas corporais (urucum e suco de jenipapo) e, além disso, eles exibiam certa resistência aos efeitos das picadas. Von Spix e von Martius (1938) descreveram que os índios remadores não se perturbavam com as nuvens de mosquitos que atacavam suas costas, diferentemente da situação desesperadora dos naturalistas. Para se verem livres dos incômodos insetos alados, eles se fechavam em cabanas enfumaçadas, mas o odor fétido e insalubre provocava a saída em busca de ar puro, ocasião em que o pobre coitado se via entregue a uma nova sequiência de ataques das criaturas hematófagas. Outra solução era se meter em roupas pesadas e cobrir o rosto com um véu, mas o desconforto era enorme e havia o risco de desidratação. 
As expedições científicas contavam com a ajuda dos índios, os quais estavam em seu próprio meio e conheciam os caminhos. Eles detinham conhecimentos valiosos e emprestavam suas habilidades para obtenção do alimento e construção de abrigos em plena selva tropical. Von Spix e von Martius (1938) tiveram oportunidade de perceber o valor das habilidades dos índios. Certa ocasião, a comitiva se perdera em plena selva e teve que interromper a marcha em razão da escuridão da noite e uma chuvinha que deixara a todos encharcados. Os índios rapidamente construíram um abrigo com cascas de árvores e folhas de palmeiras e improvisaram o leito com samambaias. A situação não era de toda desconfortável e von Martius chegou a se movimentar para preparar um café, mas praguejou ao notar que havia esquecido de trazer vasilha para ferver a água. Um índio veio em seu socorro. Ele usou uma folha nova e ainda não rachada do coqueiro pati (Cocos batryophora), deu-lhe a forma de uma canoa e a encheu de água; o recipiente foi bem amarrado e levado ao fogo. Os exploradores ficaram espantados, pois a água fervera sem arrebentar a panela vegetal. Foi uma aula sobre a resistência dos materiais regada à saborosa bebida das arábias!

Alguns naturalistas tinham sangue nobre e acreditavam que o Brasil era o El Dorado das ciências. Um desses personagens é o Príncipe Adalberto da Prússia (1811-73), que visitou o Brasil (5 de Setembro/1842 a 3 de Janeiro/1843) e descreveu os desconfortos que os homens enfrentavam no meio das matas. Ele se fez acompanhar do Conde de Oriolla, capitão de Estado Maior, Conde Bismarck (1815-98), Herr Theremin, cônsul prussiano no Brasil, Dr. Lippold, Padre Torquato Antonio de Sousa e ajudantes indígenas. Adalberto se encontrava em viagem pela Itália e, ao término desta, recebeu apoio logístico para esticar o tour até o Brasil. Ele visita o Rio de Janeiro e chega até à Belém, onde fica extasiado com a exuberância do cenário tropical. A viagem foi feita de barco, intercalada por explorações no interior das selvas. Para garantir o sucesso da expedição, Adalberto fora aconselhado a recorrer aos préstimos de Torquato, padre que vivia num vilarejo perdido no meio das selvas amazônicas. Ele fica aborrecido com a idéia, pois imagina que um padre seria um estorvo para suas explorações, mas fica admirado ao se deparar com o oposto daquilo que imaginara: Torquato era um jovem de porte atlético e de boa conversa. Ele era bem conhecido dos índios e a sua aparência acaboclada nada lembrava a figura de um sacerdote. Era Torquato quem liderava marcha e a comitiva tinha dificuldades em acompanhar suas vigorosas passadas.

Os membros da expedição eram completamente inexperientes, mas a ajuda dos índios e a presença do valoroso Torquato prenunciavam que o empreendimento teria pleno sucesso. Adalberto descreve com humor as dificuldades enfrentadas pela comitiva, como a alimentação preparada pelos índios e o 
modo como eles davam conta das bolachas de campanha, as quais eram amolecidas a golpes de martelo! Os nativos capturavam tartarugas e usavam o próprio casco do animal para assá-lo ainda vivo - o odor da incineração do casco e os esperneios do animal causavam profundo terror. Certa ocasião, Oriolla chamou as atenções dos índios quando trocava de camisa. A cena causou espanto aos índios; eles convocaram as mulheres e os filhos e apalparam cuidadosamente o corpo de Oriolla, pois pareciam interessados em saber se aquele "capricho da natureza" era verdadeiro. Os nativos nunca haviam visto pele tão branca!

No meio da caminhada e em plena floresta amazônica (3 de Dezembro/ 1842), a comitiva interrompe a marcha para o repouso noturno. O céu estava límpido e os índios rapidamente montam o toldo e acendem uma fogueira. Após uma refeição improvisada, todos se entregam ao sono e Adalberto permanece algum tempo contemplando as estrelas, enquanto reinava o silêncio e a fogueira aquecia os corpos. O cenário era enternecedor, mas repentinamente os homens acordam com uma terrível chuvarada; eles se ajeitam como podem e retornam ao sono. $\mathrm{O}$ aguaceiro perde força, mas a trégua é seguida por outro ainda mais intenso e mais duradouro. Os homens buscam refúgio embaixo do toldo e as carnes humanas se transformam em paredes do precário abrigo. Um horror. Adalberto tinha pavor relação às formigas e aos insetos gosmentos da Amazônia, sentimento compartilhado por Herr Theremin e Oriolla. Os dois ficam sensibilizados com os infortúnios de Adalberto e oferecem o compartilhamento de suas redes. Ele aceita a oferta, mas a escuridão era enorme - 0 segundo aguaceiro apagou completamente a fogueira - e as redes balançavam com os esforços para acomodar a carga adicional. Foi pura perda de tempo. Por seu turno, os índios dormiam tranquilamente e o Padre Torquato havia se metido dentro de seu barrete, fechando-se para os humores da natureza. $\mathrm{O}$ aguaceiro parecia que estava indo embora, mas o primeiro e o segundo pareciam ser um preparativo para o verdadeiro dilúvio tropical que veio a seguir. Ao notar que Dr. Lippold dormia sem cobertor, Adalberto se esgueira até ele com seu cobertor e se acomoda em sua rede, mas ela não resiste ao peso e os dois desabam no chão. Cansado dos aborrecimentos, Adalberto rasteja em busca de refúgio debaixo do toldo, onde os índios já ocupavam os melhores lugares. O seu corpo estava encharcado e ele mantinha a cabeça enrolada num poncho, acima do chão - o sono não era possível, pois ele não tinha onde apoiar a cabeça. Ele se esgueira para o centro do abrigo, mas encontra resistência na massa de carne que se movimentava na mesma direção; os índios dormiam no centro do abrigo, enquanto Adalberto, Lippold e Oriolla ficaram na chuva. A movimentação dos homens derrubou as estacas do abrigo e todos tiveram que rastejar às cegas para minimizar os desconfortos. A peça desmontada resultou na formação de uma calha - as águas eram direcionadas à cabeça de Adalberto e, 
agora, ele corria o risco de morrer afogado! Ele rasteja na escuridão, mas fica entalado entre dois índios nus. A situação era constrangedora para um homem de linhagem nobre, mas pelo menos o calor das carnes desnudas proporcionava certo conforto. Os insetos não davam trégua e o aguaceiro parecia anunciar o fim dos tempos. Esgotado pelos aborrecimentos, o príncipe Adalberto finalmente se rende ao sono: "- esquecendo todas as formigas do Brasil, adormeci por fim suavemente e dormi até o amanhecer" (p. 268). ${ }^{4}$

Muitos naturalistas voltaram das expedições com graves enfermidades (e.g., verminoses, esquistossomose, malária e intoxicação alimentar), sem contar os motins, deserções e mortes inesperadas dos homens (ver VANZOLINI, 1996). Além dos insetos, répteis e riscos de se perderem por falta de mapas, os naturalistas conheciam outras peculiaridades nada agradáveis das matas tropicais. Após um período de chuva, o material orgânico entrava em decomposição e começava a exalar um odor fétido. O príncipe Adalberto relatou a provação e alguns membros da expedição de von Spix e von Martius (1938) chegaram a ter desmaios ou calafrios diante dos "eflúvios mefíticos" que exalavam após uma chuvarada.

Muitas vidas se perderam nas expedições, como ocorreu com Friedrich Sellow (1789-1831) que se afogara aos 42 anos nas águas do rio Doce, Minas Gerais (FERRI, 1955). A expedição liderada pelo Barão Georg Heinrich von Langsdorff (1742-1852) também exemplifica os perigos enfrentados por esses homens. $\mathrm{O}$ alemão tinha bom domínio do idioma português e fora designado Cônsul Geral da Rússia, sediado no Rio de Janeiro. Ele era dono da fazenda Mandioca, na base da Serra dos Órgãos, onde plantava café, milho, banana e mandioca e recebia com generosidade os naturalistas estrangeiros que visitavam o Brasil. A expedição Langsdorff (1825-29) foi financiada pela Rússia e contou o apoio das autoridades brasileiras; ela produziu um vasto material de valor artístico, mas foi um "triste fracasso" do ponto de vista zoológico (ver VANZOLINI, 1996). As trapalhadas começaram logo no início, pois o zoólogo J.M. Edouard Ménétriès se desentende com Langsdorff (1825) e é substituído por Christian Hasse. Este se apaixona por uma jovem de Campinas, mas a moça abre as portas do coração à Hercule Florence, outro membro da expedição. O consórcio amoroso dá surgimento a uma ilustre família campineira, mas Hasse abandona a expedição. No que diz respeito às fatalidades, contam-se a morte de Aimé-Adrien Taunay, jovem artista plástico que se afogara quando tentava atravessar a nado as águas do rio Guaporé (1826), no Mato Grosso, e o profundo debilitamento físico e mental de Langsdorff e do astrônomo N.G. Rubtsov. A comitiva enfrentou fome e os ataques dos mosquitos; as provisões foram minguando e o líder da expedição começou a exibir uma profunda perturbação mental (amnésia, delírios, letargia e incapacidade de dizer coisas inteligíveis).

\footnotetext{
"Príncipe Adalberto da Prússia. Brasil: Amasonas-Xingul. Coleção "O Brasil visto por estrangeiros". Brasília: Senado Federal, 2002.
} 
A elaboração final dos diários ficou aos encargos de Florence, pois a insanidade de von Langsdorff o impedia sequer de saber o dia em que eles estavam (ver KOMISSAROV, 1992).

\section{As ciências naturais}

As ciências naturais tiveram início tardio no Brasil, devido à inexistência de universidades e descuido das autoridades portuguesas em relação ao conhecimento científico. Portugal parecia ser refratário aos avanços que ocorriam na Inglaterra e França, mas a situação era calamitosa em relação ao Brasil. A colônia parecia estar murada em relação ao mundo e alguns avanços começaram a ocorrer a partir de 1808 , ocasião em que as tropas napoleônicas invadem Portugal e o príncipe regente transfere a corte para o Brasil. Talvez para atenuar um pouco a imagem de colonizador anti-civilizatório ou, o que é mais provável, para dissipar um pouco o aspecto bronco e atrasado do ambiente a que ele fora condenado a viver, o então príncipe D. João promove a instalação de importantes instituições científicas. É nessas circunstâncias que surgem o Jardim Real (13 de Junho/1809) e o Museu Real (26 de Maio/ 1818), os quais passaram a ser designados Jardim Botânico e Museu da Quinta da Boa Vista. Essas instituições surgiram tardiamente e trouxeram benefícios científicos, mas a abertura dos portos às nações amigas (28 de Janeiro/ 1808) foi a medida que permitiu a inserção do Brasil no cenário científico. A partir desse momento, o Brasil começou a receber visitas de ilustres naturalistas, como os alemães Georg W. Freyreiss (1813), Friedrich Sellow (1814) e o Príncipe Maximilian Wied-Neuwied (1815) e o francês Auguste de SaintHilaire (1818).

As ciências naturais progrediam lentamente e os visitantes praticavam o que hoje designaríamos como biopirataria: eles vinham ao Brasil, contratavam tropeiros, coletavam material (e.g., animais, plantas, amostras geológicas e fósseis) e retornavam aos seus países com os navios abarrotados de nossas riquezas. O Brasil era o sonho dos naturalistas; os museus da Europa se enriqueciam com os nossos tesouros, mas os visitantes não deixavam discípulos e escondiam os resultados de seus estudos em periódicos inacessíveis aos brasileiros. Além do financiamento por parte de seus países de origem, os naturalistas estrangeiros contavam com o suporte logístico oferecido por D. Pedro II e demais autoridades. O espírito subserviente de nossas autoridades foi denunciado por João Barbosa Rodrigues (1842-1909), naturalista que deu os rumos à moderna botânica no Brasil, e Arthur Neiva (1880-1943), um dos notáveis cientistas relacionados ao grupo de Oswaldo Cruz (ver TRAVASSOS, 1944; DE SOUZA, 2009). 
Um bom exemplo dessa política equivocada foi a dilapidação das cavernas e sítios paleontológicos de Lagoa Santa, município de Minas Gerais. O dinamarquês Peter Wilhelm Lund (1801-80) tornou a região conhecida no mundo inteiro e suas descobertas tiveram enorme significado paleontológico; ele descreveu os animais (54 gêneros e 114 espécies, algumas gigantescas) e os hominídeos que habitavam as cavernas de Maquiné e Sumidouro (DE AZEVEDO, 1950). Lund viveu cerca de 50 anos na bacia do rio das Velhas e, prenunciando a morte, doou a sua enorme coleção de fósseis ao Museu de Copenhague (LEINZ, 1955). O naturalista Luís Agassiz (1807-73) também coletou uma quantidade fabulosa de peixes no país e encontrou tempo para visitar Lagoa Santa. A intenção era coletar algum material de valor científico, mas ele ficou frustrado ao encontrar as cavernas totalmente despojadas de conteúdo - Dr. Lund chegara primeiro! Os dois naturalistas são nomes respeitados no mundo das ciências, mas suas explorações pouco ou nada beneficiaram o Brasil.

As circunstâncias que cercaram a expedição de Agassiz exemplificam o descaso dos antigos governantes com o futuro de nossas instituições. Agassiz nasceu na Suíça, mas migrou com seus pais para os EUA e lá fundou o $M u t-$ seum of Comparative Zoology (1859); ele foi influente educador na Lawrence Scientific School e deu importantes contribuições à paleontologia. Agassiz foi o primeiro a postular que a Europa e demais continentes passaram por um período glacial, mas acreditava que as espécies eram organismos inıutáveis e independentes uns dos outros. No inverno de 1864-65, ele se encontrava com a saúde debilitada e seus médicos recomendaram uma mudança de ares. Ele relatou os infortúnios ao amigo Nathaniel Thayer (1769-1840), informandoo que gostaria de passar umas férias no Brasil. Thayer ouviu atentamente e lhe ofertou os recursos necessários para associar o repouso a uma empresa verdadeiramente científica (i.e., coleta de material para o Museu de Cambridge). A oferta era sedutora demais para ser recusada e, com efeito, Agassiz e Mrs. Elizabeth Cary Agassiz dão início a uma fabulosa aventura pelo interior do Brasil (Voyage au Brésil, 1869) ${ }^{5}$.

Os antigos exploradores eram homens rudes e bem preparados, diferentemente do adoentado Agassiz e de sua rechonchuda esposa - os dois eram rechonchudos! A expedição Thayer, como ela ficou conhecida, foi cercada de conforto, pois as autoridades americanas facilitaram o transporte e os desentraves aduaneiros, enquanto D. Pedro II punha à disposição de Agassiz um navio de guerra e lhe dava um salvo-conduto para coletar o material que desejasse. Índios, caboclos e alunos das escolas primárias eram colocados à disposição de Agassiz; eles enchiam os barcos com material variado e até o Padre Torquato chegou a ser elogiado por suas contribuições ao sucesso da expedição Thayer.

${ }^{5}$ L. Agassiz \& E.C. Agassiz. Viagem ao Brasil (1865-1866). Coleção "O Brasil visto por estrangeiros". Brasília: Senado Federal, 2000. 
As autoridades das províncias tomavam conhecimento do dócumento emitido por D. Pedro II e pareciam se envolver numa competição para cercar ainda mais o casal Agassiz de confortos; a visita era motivo para festas e todo o tipo de comemorações. As senhoras dos vilarejos envolviam a esposa de Agassiz em longas reuniões para chás, enquanto que o Sr. Antonio Pimenta Bueno, Marquês de São Vicente, colocava à disposição do naturalista um dos mais belos vapores de sua companhia - o ambiente espaçoso e os confortos da embarcação permitiam que Agassiz se sentisse como se estivesse em seu museu nos EUA. Ele encontrava novas coleções de peixes a cada porto visitado, pois o zeloso Pimenta Bueno enviava seus barcos à frente com ordens para providenciar novos mimos ao ilustre visitante.

Agassiz coletou uma fabulosa quantidade de material de importância científica e chegou a prenunciar que faria uma revolução nos conhecimentos ictiológicos. As autoridades brasileiras se rejubilavam com o interesse do naturalista pelas nossas coisas, como pode ser visto num documento oficial (13 de Novembro/1865) emitido por Antonio Epaminondas de Melo, presidente da província amazônica. O contentamento do presidente chega a transbordar no curto documento: ele manifestava os agradecimentos pela visita e, em nome do povo amazônico, desejava ardentemente o pleno sucesso da expedição Thayer, só lamentando o curto tempo de permanência na região e não poder dispor de mais recursos para colocar à disposição de Agassiz.

O naturalista era um sábio que apreciava a intimidade com os financistas e políticos influentes, enquanto D. Pedro apreciava o relacionamento com os sábios (VANZOLINI, 1996). Foi uma feliz conjugação de interesses, mas não rendeu bons frutos ao Brasil e serviu mais para ilustrar a falta de clarividência das nossas autoridades. Ao final do livro, Agassiz agradece os esforços de D. Pedro II, pois o imperador proporcionou todas as condições para o sucesso da expedição e lhe presenteou com uma belíssima coleção de peixes do Rio Grande do Sul. Agassiz se esbaldara diante das bajulações, enquanto que o nosso Museu Imperial vivia em estado calamitoso, sem melhorias e acréscimos nas coleções. Ele próprio visitou o local e concluiu que "era uma antiqualha": o acervo era pobre e não havia preocupação com as melhorias e acréscimos. Os interessados na magnífica fauna ictiológica da Amazônia não deveriam perder tempo visitando o museu da capital, pois "far-se-ia uma melhor coleção, numa só manhã, no mercado da cidade" (p. 458). Outros viajantes teceram comentários depreciativos acerca do Jardim Botânico e Museu Nacional, cujos acervos eram absolutamente incompatíveis com as riquezas do Brasil (ver BEDIAGA, 2007).

As autoridades cercaram Agassiz de comodidades e ele realizou uma coleta de grande valor científico, mas não se viu na obrigação de sequer comentar a cordialidade de nosso povo. Com efeito, ele emite comentários depreciativos à respeito dos brasileiros, os quais nada teriam do vigor físico e 
intelectual dos povos anglo-saxônicos; ele era segregacionista e exibia certo horror ao ver as crianças brancas brincando junto com os negrinhos das mucamas. O naturalista chega a recomendar que sejam abertas todas as portas para a educação do negro, pois assim se garante a elevação moral e intelectual, mas é importante que "respeitemos as leis da natureza e, em nossas relações com os negros, mantenhamos no seu máximo rigor, a integridade do seu tipo original e a pureza do nosso" (p. 282).

O Brasil recebeu muitos naturalistas durante o período colonial, mas alguns se fixaram no país e deram notáveis contribuições ao desenvolvimento de nossas ciências naturais. Um deles foi Theodor Peckolt (1822-1912), químico alemão que estudara minuciosamente as nossas plantas. Ele chegou ao Brasil em plena mocidade e aqui permaneceu os 65 anos restantes de sua vida. Peckolt se empregou numa botica no interior de Minas Gerais e conseguiu amealhar algum dinheiro. suficiente para comprar um cavalo e dar início a uma viagem de estudos às províncias de Minas Gerais, Espírito Santo e Rio de Janeiro. Von Martius o tinha em alta conta, pois os dois mantinham correspondência regular e trocavam informações científicas; o naturalista bávaro chegou a enviar manuscritos e descrições originais para que o jovem Peckolt providenciasse as correções (DOS SANTOS et al., 1998).

Theodor Peckolt se fixou definitivamente no Brasil e abriu as portas aos estudos das plantas medicinais, bem como deu novos rumos à indústria da canade-açúcar. Ele associava os conhecimentos da química com a botânica e mostrou que muitas plantas brasileiras tinham importantes efeitos terapêuticos. Outros naturalistas estrangeiros que deixaram marcas institucionais em solo brasileiro foram Hermann von Ihering (1850-1930), alemão que fundou o Museu Paulista e o dirigiu por muitos anos (1894-1915), e Emilio Goeldi (18591917), suíço-alemão e fundador do Museu Paraense, que atualmente leva o seu nome. Com todas as falhas e possíveis vieses nacionalistas - conta-se que Goeldi não tinha muito apreço pelos brasileiros, preguiçosos e poucos afeitos ao trabalho científico -, esses naturalistas pertencem a uma categoria distinta dos antigos exploradores.

\section{Anatomia de uma monstruosidade}

Os antigos naturalistas enfrentavam inúmeras dificuldades para a coleta de material e o acervo muitas vezes se deteriorava com o tempo, em razão da negligência ou falta de apoio às instituições científicas. Durante o período colonial, o Brasil não dispunha de artesãos gráficos e livreiros e, portanto, os livros eram publicados em gráficas de Portugal ou da França. Tal como ocorrera com a obra de Frei Vicente do Salvador, é possível que muitos tesouros ainda estejam por serem descobertos pelos historiadores. 
Os esforços para publicação eram enormes e o pensador original enfrentava outro tipo de problema: o plágio. Os historiadores copiavam uns aos outros e frases, parágrafos ou páginas inteiras eram expropriadas sem sequer a menção da fonte original. Isso ocorreu com as descrições dos rituais da antropofagia e dos estranhos animais que habitavam o Novo Mundo.

Francisco López de Gómara (1511-66) nunca pisou nas Américas, mas escreveu um dos livros mais interessantes sobre a colonização espanhola (Historia de la conquista de Mexico, 1552). Análises mais atentas revelaram que Gómara copiou vários trechos da obra de outros autores (OSTOS, 2006). Ele não deu nenhuma satisfação aos seus leitores ou sequer tentou minimizar a expropriação com a citação da fonte original, pois assim procedendo poderíamos julgar que se tratasse de falta de imaginação ou preguiça para dar formas originais às idéias alheias. Entretanto, tudo isso são apenas pecadilhos diante de algo ainda mais grave: expropriações de coleções e obras científicas. Enquanto o velho Gómara copiava trechos ou páginas de outros autores, a Botânica brasileira teve manuscritos originais expropriados por Etienne Geoffroy de SaintHilaire (1772-1844).

As expropriações ocorreram após a invasão de Portugal pelas tropas napoleônicas (17 de Novembro/1807), lideradas pelo General Jean-Andoche Junot (1771-1813). Junot não encontrou muitas dificuldades para pisar em solo português, mas, para evitar tumultos e rebeliões, ele teve o cuidado de anunciar que estava em missão pacífica: - Napoléon, mon mäitre, m'enviaie pour vos proteger - je vous protegerai. A frase ganha um tom jocoso entre os portugueses, como quando dois amigos simulam um combate: "- Espera aí que vou proteger o teu nariz com dois murros!". Conta-se que Junot chegou à Portugal com 5.000 homens, os quais se encontravam famintos e extenuados. Eles invadiram os conventos e mosteiros em busca de alimento e abrigo, mas logo se apossaram de peças de ouro e prata, destruíram obras de arte e livros antigos. $O$ general francês era jovem e inexperiente e não exercia autoridade sobre seus comandados, de modo que até os túmulos foram violados em busca de coisas de algum valor.

Os soldados de Napoleão vieram em missão de paz - assim eles diziam! e desejavam apenar libertar o povo português da tirania de seu rei, mas encheram os carroções com pias batismais, relíquias de prata que adornavam os altares e itens de grande significado histórico. Muitos manuscritos originais se perderam diante do vandalismo ou foram enviadas para a França. No contexto científico, as expropriações mais significativas se deram em relação às obras de Alexandre Rodrigues Ferreira (1756-1815) e do Frei José Mariano da Conceição Velloso (1742-1811). O primeiro é considerado o primeiro naturalista brasileiro; ele era natural de Salvador/BA, graduou-se em medicina na Universidade de Coimbra, Lisboa, e empreendeu uma expedição ao norte do Brasil (1783-92), 


\section{Padre Raulino Reitze as ciências naturais no Brasil}

epopéia que ficou conhecida como "Viagem filosófica". Frei José nasceu numa região que atualmente leva o nome de seu primo (Tiradentes/MG) e deu importantes contribuições ao conhecimento da flora brasileira. Tais empreendimentos eram partes de um projeto de revitalização econômica de Portugal, implantada pelo Marquês de Pombal (1699-1782), que tinha como base o conhecimento e a exploração racional dos recursos naturais das colônias (ver DE CARVALHO, 1987; CARDOSO, 2003).

Ferreira era bem conceituado junto à Domenico Vandelli (1735-1816), naturalista italiano que fora designado pelo Marquês de Pombal a promover reformas no ensino de Portugal. Contando com o apoio de seu mentor, ele percorre os estados do Pará ao Mato Grosso; as coletas foram feitas nos rios Amazonas, Negro, Branco, Madeira e Guaporé. A "Viagem filosófica" produziu um amplo e variado material (manuscritos, anotações, desenhos e exemplares da fauna e flora), o qual é enviado à Lisboa para compor os museus e publicação de livros. Ao instalar suas tropas em Portugal, Junot determina à Vandelli que todo o acervo científico do Museu da Ajuda fosse colocado à disposição de Saint-Hilaire. Napoleão sabia da importância desse acervo e, portanto, foi assim que os manuscritos e os desenhos de Ferreira foram expropriados; Saint-Hilaire catalogou várias espécies da fauna brasileira sem nunca ter postos os pés no Brasil. O vergonhoso episódio foi denunciado por Arthur Neiva (1929) e encontra respaldo nos documentos e depoimentos de cientistas das terras lusas e brasis (ver DE AZEVEDO, 1950; FERRI, 1979; VANZOLINI, 1996).

A expropriação de idéias alheias é algo condenável em qualquer tempo e em qualquer lugar, mas a estatura científica de Saint-Hilaire foi ainda mais encorpada com outro episódio. Munido de uma carta do General Junot, que se auto-proclamara Duque de Abrantes e comandante das forças armadas portuguesas, ele teve livre acesso à Imprensa Régia de Lisboa (29 de Agosto/1808) e se apodera dos manuscritos e das 554 chapas relativas ao livro de Frei José, o mineiro que conciliava as obrigações sacerdotais com o amor às ciências naturais. Frei José descrevera várias espécies de plantas, entre as quais o andá-açu, árvore frondosa cujo nome científico é uma homenagem a D. João VI: Joannesia princeps. O manuscrito expropriado (Flora fluminensis) descrevia 1.700 espécies e era ricamente ilustrado com os desenhos de Frei Francisco Solano.

A rapinagem napoleônica foi bem documentada: estima-se que, entre 1803 e 1808, escaparam das mãos portuguesas centenas de exemplares de espécies da fauna (mamíferos, aves, répteis, insetos e crustáceos), dois herbários com 2855 espécies da flora, fósseis raros e amostras geológicas. As expropriações dos manuscritos inéditos de Alexandre R. Ferreira e do Frei José são os casos mais conhecidos, mas algumas fontes mencionam que foram expropriados cinco manuscritos. Uma boa parte do material foi devolvida em 1814 , 
mas o Museu da Ajuda já se encontrava em dificuldade e as depredações agravaram ainda mais o desenvolvimento das ciências naturais de Portugal, com repercussão ainda mais negativa para o Brasil. Saint-Hilaire era um naturalista respeitado, mas a sua audácia manchou definitivamente a sua reputação. Um conhecido botânico apontou que os brasileiros não iniciaram de modo feliz na Botânica, pois "dois dos nossos pioneiros foram, parece incontestável, vítimas da falta de escrúpulos de um cientista estrangeiro" (FERRI, 1955; p. I83).

Frei José era reverenciado por seus pares e a sua obra foi importante sob vários aspectos. Felizmente, ele consegue reaver os manuscritos e desenhos, os quais são encaminhados ao Convento de Santo Antonio, no Rio de Janeiro/ RJ (1809). Após a sua morte, o material é encaminhado à Real Biblioteca (13 de Novembro/1811), onde permanece esquecido até a descoberta pelo Padre Antonio de Arrábida. Ao tomar conhecimento do manuscrito, D. Pedro I ordena a sua publicação. Ficou acertado que a obra teria uma tiragem de 3.000 exemplares e, para tanto, foi contratada uma livraria na França. O destino novamente conspirou contra Frei José, pois D. Pedro I abdica do trono e, sem sabermos os reais motivos, o novo governo não ordena o pagamento dos serviços prestados pela livraria francesa. Para minimizar o prejuízo, os exemplares de Flora fluminensis são vendidos como simples papelório e encontram serventia nas fábricas de cartuchos de guerra.

O ilustre capuchinho contribuiu significativamente para o conhecimento da nossa flora e enfrentou as adversidades de seu tempo. Em 22 de Outubro/ 1850, foi criada a Sociedade Vellosiana de Ciências Naturais, no Rio de Janeiro/RJ. Ela iniciou suas atividades com doze sócios efetivos, entre os quais Francisco Freire Allemão de Cysneiros (1797-1874), fundador e presidente, Emilio Joaquim da Silva Maia (1808-59) e Alexandre Antonio Vandelli (1784-1862), filho de Domenico Vandelli. Ela tinha como objetivo estimular as ciências naturais (Botânica, Zoologia, Geologia e Ciências Físicas e a Etnografia). Durante a sua curta existência, a Sociedade Vellosiana enfrentou vários problemas (competições internas e falta de recursos orçamentários), mas também contribuiu para o seu desaparecimento a falta de apoio de D. Pedro II - ele era freqüentador assíduo de reuniões científicas, mas nunca prestigiou os eventos da sociedade (MARQUES \& FILGUEIRAS, 2009).

\section{O nascimento da botânica no Brasil}

O primeiro compêndio de botânica foi escrito pelo baiano Antonio Mariano do Bomfim (Elementos de anatomia, physiologia e morphologia vegetal, 1873). Em seguida, veio a contribuição do também baiano Joaquim Monteiro Caminhoá (Elementos de botânica geral e médica, 1877), 
obra publicada em três volumes e que por muito tempo foi a principal referência aos interessados nos assuntos relativos às plantas. Outras contribuições importantes foram os dicionários e obras que listavam a terminologia científica e nomes comuns das plantas, como o Dicionário de botânica brasileira (1873) e Phytographia, ou botânica brasileira applicada à medicina, às artes e à indústria (1881). O primeiro foi coordenado por Joaquim de Almeida Pinto, o segundo foi elaborado por Alexandre José de Mello Morais; ambos apresentavam as nomenclaturas científicas e as variações nas designações vulgares.

Alexandre R. Ferreira e Frei José são personagens que se destacam na história das ciências naturais, mas a moderna botânica brasileira surge a partir da obra de João Barbosa Rodrigues (1842-1909), carioca de nascimento que alcançou prestígio internacional. Ele despendeu três anos coletando material no Amazonas (1871-74) e, ao retornar a este estado, ele instala o Museu Botânico, sendo seu diretor até 1889. Após esse período, ele retorna ao Rio de Janeiro para assumir a direção do Jardim Botânico; ele amplia o acervo e classifica as espécies, sem interromper as coletas nos estados vizinhos e no Sul do Brasil. Barbosa Rodrigues foi um pesquisador produtivo e sua obra mais conhecida é Sertum palmarum Brasiliensium (1903). Ele tinha interesses variados, pois estudara as línguas e os costumes dos indígenas e dera contribuições para a arqueologia e paleontologia. As belas ilustrações de seus trabalhos eram feitas por sua esposa, Dona Constança, e algumas delas se transformaram e reproduções toscas e incolores nas obras de naturalistas estrangeiros. Barbosa Rodrigues foi defensor da propriedade intelectual e não se esquivou de lançar críticas aos governantes de sua época, os quais abriam as portas aos naturalistas estrangeiros e praticamente tornavam os nossos cientistas subservientes aos seus propósitos (SÁ, 2001).

O surgimento tardio de nossas instituições científicas é algo desconcertante; a instalação da corte portuguesa no Brasil (1808) promoveu o surgimento da Imprensa Régia, escolas de medicina e o primeiro jornal impresso no país (A Gazeta do Rio de Janeiro, 10 de Setembro/1808). Entretanto, avanços mais amplos vieram com a instalação da Academia Brasileira de Ciências (1916, Rio de Janeiro/RJ), agremiação congregava os naturalistas e que impulsionou o desenvolvimento de nossas ciências. Algo ainda mais significativo foi a criação da Universidade de São Paulo (1934), que ocorreu durante o governo de Armando de Salles Oliveira (1887-1945). O Brasil já contava com algumas instituições de ensino superior, mas elas eram apenas aglutinações de faculdades, funcionavam precariamente e suas ações eram direcionadas unicamente ao ensino. A instituição paulista foi criada de modo diferente e seus dirigentes buscaram as melhores inteligências no Brasil e no exterior para compor seus departamentos. É com acerto e justiça que muitos consideram que USP foi a primeira universidade instalada no Brasil. 
O Departamento de Botânica era parte integrante da Faculdade de Filosofia, Ciências e Letras. Muitos imaginam que uma universidade deva ser voltada para o ensino, mas a investigação científica é a sua essência, a sua alma. Com efeito, Teodoro A. Ramos (1895-1937) convidou o alemão Felix Kurt Rawitscher (1890-1957) para organizar e administrar o departamento. Ele era professor de botânica florestal, da Universidade de Freiburg, aceitou prontamente o convite e deu início a um sistema inovador de ensino: a cada aula teórica, duas aulas práticas; a qualidade obedecia aos padrões internacionais. Rawitscher criou o periódico Boletim de Botânica (1937) e publicou um manual (Elementos básicos de botânica geral, 1940), minimizando as dificuldades que os alunos encontravam para localizar obras escritas no idioma português (DE MORRETES, 1994). A USP contribuiu decisivamente para a consolidação do ensino superior, associando-o às investigações científicas.

A política de contratação e os procedimentos adotados na instalação da USP foram inovadores, pois havia a genuína preocupação com a investigação científica. Tudo isso contrasta com o atual cenário das universidades federais brasileiras: os laboratórios se encontram desaparelhados, o ensino é de acordo com "a realidade brasileira" e os cargos mais importantes são ocupados pelos mais loquazes. Por ocasião da instalação da USP, predominava certo xenofobismo em relação aos professores estrangeiros, mas eles vieram para trabalhar e a maioria se fixou definitivamente no país. Dois textos descrevem bem o desenvolvimento da botânica a partir da instalação da Universidade de São Paulo (ver FERRI, 1955, 1979). A partir desse novo cenário, em 1950 é criada a Sociedade Botânica do Brasil.

\section{Naturalistas do Sul}

O Estado de Santa Catarina foi visitado por ilustres naturalistas, entre os quais Adam Johann von Krusenstern (1803), Urey Lisiansky (1803), Barão Langsdorff (1803), John Mawe (1807), Adalbert von Chamisso (1815) e Carl F.G. Seidler $(1825)^{6}$. Descrições sobre a biodiversidade se misturam com comentários acerca da beleza da Ilha do Desterro, a atual Florianópolis, mas obras mais recentes discutem a importância da colonização alemã na formação da identidade catarinense.

O povo alemão é conhecido por seu relacionamento especial com natureza. Os colonos que se instalaram no Sul do país eram excelentes agricultores e essa característica explica o elevado padrão de vida herdado por seus descendentes.

"Illa de Santa Catarina - relatos de viajantes estrangeiros nos séculos XVIII e XIX. Florianópolis: Assembléia Legislativa do Estado de Santa Catarina, 1979. Ver também: C. de Mello Leitão. Visitantes do Primeiro Império. São Paulo: Melhoramentos. 1934. 
É comum os moradores cultivarem suas hortaliças e praticamente não existe uma moradia que não seja cercada por árvores frutíferas ou que não ostente à frente um florido jardim. Essas peculiaridades explicam a boa performance agrícola dos estados sulistas, bem como os naturalistas que tinham alguma ligação com Santa Catarina. Destacam-se nesse lote os nomes de Fritz Müller (1822-97), Fritz Plaumann (1902-94), Balduíno Rambo (1905-61) e João Alfredo Rohr (1908-84). Eles eram de origem germânica, mantinham relacionamento estreito com a colônia e eram homens de espírito prático. Raulino Reitz é originário desse ambiente cultural.

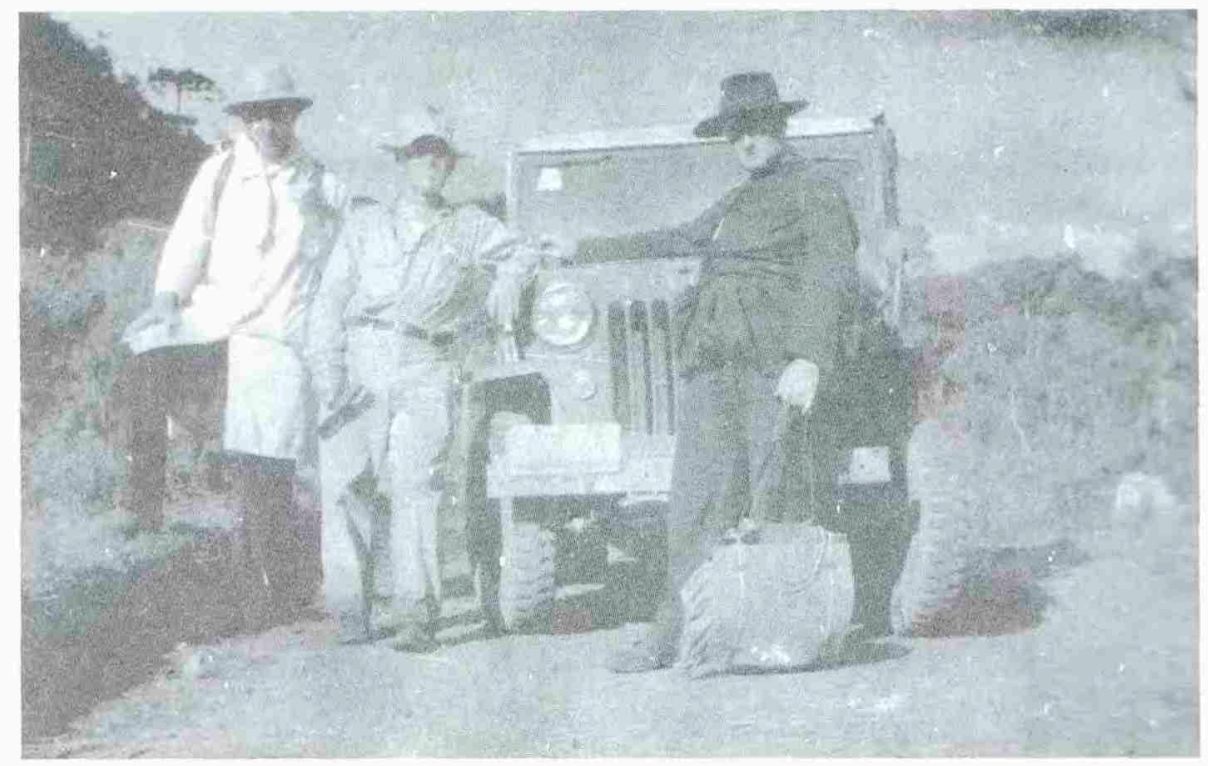

Figura 1

Pioneiros das ciências naturais durante uma expedição científica (Morro da Bela Vista, Município de Bom Retiro/SC). Da esquerda para a direita: Aloysio Sehnen, Lyman B. Smith e Padre Balduíno Rambo (Fotógrafo: Raulino Reitz).

Müller não era catarinense, mas despendera a maior parte da vida em Blumenau/SC. Ele mantinha correspondência regular com Charles R. Darwin (1809-82) e era respeitado na Alemanha e Inglaterra. Müller era um ardoroso defensor da teoria da evolução das espécies e chegou a publicar uma influente obra em favor das idéias de Darwin (Für Darwin, 1864)7, o que the trouxe alguns problemas no Liceu Provincial do Desterro (o atual Colégio Catarinense), instituição mantida pelos padres jesuítas. Ele fora demitido da instituição,

Müller, F. Para Darwin. Florianópolis: EDUFSC, 2009 (ver Comentários e Necrológios). 
mas, de acordo com o respeitado historiador Oswaldo Cabral, o episódio fora mais ocasionado pelo seu ardor evolucionário e germanismo acentuado, que às intolerâncias dos padres da instituição de ensino - nem o Dr. Hermann Blumenau agüentava as excentricidades do naturalista (CABRAL, 1972). Possuidor de múltiplos recursos e excelente observador, Müller cultivava hábitos simples e parecia satisfeito com a vida de colono no Vale do Itajaí.

Os colonos alemães eram corpulentos e espadaúdos, mas as fotografias mostram que Müller era uma coisa bem diferente: extremamente magro e desconjuntado, andava descalços e quase sempre se exibia com um desproporcional chapéu de abas largas; o cajado e a barba espessa lembravam o profeta João Maria, mas por detrás da estranha aparência escondia um cérebro perfeitamente funcional. Os naturalistas da Royal Society reconheciam seus méritos e o mal-humorado Darwin o presenteou com um elogio: "o príncipe dos observadores". A sua memória foi imortalizada num epônimo científico: mimetismo mülleriano - características morfológicas compartilhadas por espécies distintas e que simulam o aspecto físico de um animal predador, como os "olhos" nas asas de certas borboletas que se assemelham aos olhos de uma coruja.

Fritz Plaumann também nascera na Alemanha e migrou com seus pais para o Brasil em plena mocidade, tendo oportunidade de criar uma fabulosa coleção de insetos (cerca de 80 mil espécimes, coletados ao longo dos 70 anos de atividade). Ele não tinha vínculo com nenhuma instituição acadêmica, pois vivia no interior de Santa Catarina e a sua coleção era mantida por interesses particulares. Isso explica as dificuldades que ele encontrou para realizar coletas e trocar material com colegas no exterior. Os entraves se deram em relação ao Instituto de Desenvolvimento Florestal (IBDF), embrião do atual Instituto Brasileiro do Meio Ambiente e dos Recursos Naturais (IBAMA), órgão criado em 1989 para fiscalizar o setor. Plaumann foi condecorado pelo governo alemão com a Grã-Cruz do Mérito Científico (1991), classificou várias espécies desconhecidas e a sua preciosa coleção deu origem ao "Museu Entomológico Fritz Plaumann", localizado no município de Seara/SC".

Müller e Plaumann contribuíram para os avanços da zoologia, diferentemente de Rambo e Rohr que emprestaram suas inteligências para o desenvolvimento da geologia, arqueologia e ambientalismo; os dois eram padres jesuítas. Rambo deu importantes contribuições para o desenvolvimento da agricultura sustentável; ele foi professor de História Natural na Universidade Federal do Rio Grande do Sul e em outras instituições, criou a revista Iheringia e foi o fundador do "Museu Riograndense de História Natural". A sua obra mais conhecida foi um estudo detalhado sobre os aspectos geológicos e paisagísticos do estado gaúcho (A fisionomia do Rio Grande do Sul, 1954), a qual até hoje serve de referência para muitos estudos.

${ }^{8}$ O diário de Fritz Planmam (M.B. Spessatto, org.). Chapecó: Argos Editora Universitária. 2001. 
A contribuição mais original foi dada pelo Padre Rohr, naturalista gaúcho que vivera e trabalhara em Florianópolis mais da metade da vida. Ele foi educador no Colégio Catarinense, desempenhou as funções de Diretor de Ensino e influenciou a formação de incontáveis talentos da vida acadêmica. O seu interesse diferenciado e os resultados de suas escavações arqueológicas deram origem ao "Museu do Homem do Sambaqui", aberto à visitação pública em 1964 e pertencente ao colégio onde ele atuou por 42 anos. Padre Rohr fez um minucioso levantamento dos sítios arqueológicos e catalogou cerca de 400 locais com vestígios da presença dos povos antigos que habitavam Santa Catarina (REIS \& FOSSARI, 2009). Ele foi um pioneiro da arqueologia no Brasil e despertou as autoridades para a preservação dos sambaquis, pois os depósitos de conchas estavam sendo usados na construção civil e na produção de fertilizantes.

Os naturalistas da região Sul se preocupavam com o futuro das instituições e preservação de nossos recursos naturais, como atestam a criação de museus, herbários e reservas biológicas. O descaso de nossas autoridades sobre tais questões é um problema sério, pois muitas coleções se perderam ao longo do tempo e temos sido vítimas de biopirataria, nome atual para as rapinagens científicas. Por mais modesta que seja uma biblioteca, a coleção de livros revela o interesse de seu proprietário acerca de um assunto ou vários assuntos, mas, após a sua morte, é comum os herdeiros se desfazerem do acervo, espalhando-o no comércio de livros usados (sebos) ou, pior ainda, deixando-o entregue à ação dos verdadeiros amantes dos livros (traças e cupins). Algo parecido tem ocorrido com o nosso patrimônio científico e cultural.

Herbários e museus de história natural são importantes, pois as coleções permitem estudos comparativos e fornece uma compreensão sobre a biodiversidade. Essas instituições são bastante visitadas por alunos de escola pública e cumprem uma importante função social: educação e estímulo às vocações científicas. As excursões de alunos tornam as aulas mais estimulantes e os folguedos da meninada trazem alegria aos pesquisadores. A preservação do acervo científico não é algo dispendioso, mas a existência dessas instituições se deve mais ao idealismo e esforços dos pesquisadores. Não obstante a importância e os custos irrisórios de manutenção das coleções científica, a situação atual é calamitosa e um episódio recente revela a gravidade do problema.

Na manhã de 15 de Maio/2010, num sábado que parecia ser igual a tantos outros, os paulistanos foram acordados com um formidável incêndio que consumiu vários galpões do Instituto Butantã, instituição de prestígio internacional que produz soros contra picadas de espécies peçonhentas. Em poucos minutos o fogaréu reduziu às cinzas uma preciosa coleção de cobras, 
aranhas, escorpiões e outros exemplares da nossa fauna; estima-se que somente as coleções de répteis e aracnídeos tinham cerca de 535 e $450 \mathrm{mil}$ exemplares de espécies preservadas em álcool e formol. As coleções foram iniciadas cerca de 120 anos atrás, resultantes dos esforços de homens como Vital Brasil (1865-1950) e seguidores, e servia de referência aos especialistas do Brasil e exterior.

Os jornais noticiaram largamente a tragédia e informaram que outras instituições vivem em idêntica situação, como o Museu Nacional (Rio de Janeiro/RJ) e o Museu Emilio Goeldi (Belém/PA). Os editoriais emitiram comentários pouco elogiosos à inação governamental, pois os recursos necessários à instalação de um sistema de prevenção contra incêndios são bem inferiores aos gastos com privilégios autoconcedidos pelos políticos ou são insignificantes em relação aos desvios de verbas, praga que debilita nossas instituições governamentais. A precariedade das instalações já havia sido motivo de preocupação do Conselho de Curadores, pois os dirigentes do Instituto Butantã haviam solicitado uma verba de R\$ 1 milhão (Dezembro/2009) para efetuar melhorias e instalação de um sistema contra incêndios. O pedido fora encaminhado à FAPESP e o pedido estava sendo examinado, mas veio o fogaréu e consumiu o precioso acervo da instituição criada por Vital Brasil.

\section{Explicações sobre religiosidade e vocação naturalista}

A tradição judaico-cristã ensina que o seu humano é a criatura preferida de Deus, mas isso não significa que os demais seres vivos não sejam merecedores de respeito e compaixão. Os recursos naturais devem ser utilizados com parcimônia, pois até o relacionamento harmonioso entre as espécies (equilíbrio sustentável) é obra de Deus. Os missionários exibiam maravilhamento em relação à variedade de plantas e beleza dos pássaros, especialmente o beija-flor cuja delicadeza era algo extraordinário aos olhos dos europeus. Padre Anchieta exibia uma atitude extravagante em relação aos animais: ele se fazia acompanhar das feras em suas andanças pelas selvas, os pássaros se reuniam sobre a sua cabeça para protegê-lo dos raios solares; conta-se que ele se comunicava com os animais e se deixava picar pelos insetos hematófagos, pois eles necessitavam de alimento e também eram filhos de Deus.

Padre Antonio Vieira (1608-97) e S. Francisco de Assis (c.1181-1226) também exibiam reverência aos elementos da natureza. Os sermões de Vieira foram bem examinados por vários scholars, com a exceção do curioso "Sermão aos peixes" (13 de Julho/1654), no qual ele tece elogios ao 


\section{Padre Raulino Reitz e as ciências naturais no Brasil}

"comportamento atento" dos irmãos aquáticos, as únicas criaturas que foram recompensadas com o Dilúvio". O encantamento em relação à natureza é mais evidente na vida de $\mathrm{S}$. Francisco de Assis: ele tinha devoção a todos os seres vivos, especialmente os insetos e criaturas de aspecto repulsivo, e saudava os raios emitidos pelo "irmão Sol" e o brilho da "irmã Lua". Ele removia os vermes do caminho com medo de que fossem esmagados pelos passantes e, durante o frio invernal, as abelhas recebiam uma cota extra de mel e vinho para que não morressem de fome ${ }^{10}$. Francisco de Assis é o patrono do moderno ambientalismo ou proto-ecologista.

Importantes relatos sobre a biodiversidade surgiram da lavra de homens relacionados ao ofício sacerdotal, como Frei Andre Thevet (1502-90), Padre Fernão Cardim (c.1549-1625) e Frei Vicente do Salvador (1564-c.1639). Eles também contribuíram para consolidação da identidade nacional, destacando-se nesse quesito os padres jesuítas Manoel da Nóbrega (1517-70) e José de Anchieta (1534-97). Os dois detalharam a estrutura social e os costumes dos nativos, informaram o que eles comiam e suas crenças religiosas; Anchieta foi o autor de uma cartilha contendo os rudimentos da gramática do idioma Tupi. O propósito inicial era a salvação das almas, mas muitos missionários se destacaram nas ciências naturais e nos legaram obras sobre a história da colonização do Brasil. O inusitado consórcio intelectual entre formação religiosa e vocação naturalista deve ser examinado em razão dos fatores abaixo relacionados.

Educação. Os missionários estavam penetrando num mundo desconhecido e tinham que exibir certas qualidades, como liderança e bom preparo intelectual. A população medieval era quase integralmente composta por analfabetos e somente havia preocupação com a educação dos membros da nobreza, embora a educação fosse restrita aos códigos de etiqueta e de boas maneiras, para as mulheres, ou aulas de equitação, esgrima e infantaria, para os rapazes. Por outro lado, o ensino nos mosteiros e seminários era sistemático e mais aprofundado; as discussões giravam em torno da filosofia, lógica, oratória e a leitura de obras clássicas. Os livros eram escassos e praticamente inexistiam bibliotecas fora dos mosteiros e seminários, mas os jovens seminaristas tinham acesso às obras de Aristóteles e de Plínio, o velho. As memórias de Oswaldo R. Cabral descrevem o funcionamento e os rigores de uma instituição de ensino mantida pelos padres jesuítas (ver GUERRA, 2008).

Latinismo. O Latim era a lingua franca das ciências e da elite intelectual. As bibliotecas dos mosteiros e seminários eram repletas de obras clássicas e os noviços tinham contato muito cedo com as idéias mais avançadas da época. O uso regular do latim basicamente atendia a três propósitos: 1) ele permitia a comunicação entre os padres de países diferentes e distantes,

\footnotetext{
"A vida do Padre Vieira. Rio de Janeiro: W.M. Jackson Inc., 1950.

1" Jacopo de Varazze (c.1229-98). Legenda aurca. São Paulo: Companhia das Letras, 2003.
} 
2) o uso de uma língua morta auxiliava na preservação do significado correto das. frases e palavras das Sagradas Escrituras, sem os inconvenientes das adulterações que ocorrem durante o uso rotineiro, e 3) o aparato intelectual e o formalismo do Latim proporcionava o distanciamento das línguas comuns e mundanas. Além do preparo intelectual, os missionários tinham acesso quase exclusivo ao mundo das idéias (obras clássicas de filosofia e história natural). O idioma inglês atualmente é a lingua franca da ciência, mas as obras revolucionárias de William Harvey (De motu cordis et sanguinis in animalibus, 1628) e Sir Isaac Newton (Philosophiae naturalis principia mathematica, 1687) foram publicadas em Latim, a "língua dos padres".

Alguma coisa do latinismo foi preservada no rebuscado vocabulário dos juristas, mas com simples significado ornamental - é o mal-afamado "juridiquês". Nas ciências naturais o idioma ainda é útil para designar as espécies, de acordo com o sistema proposto por Carolus Linnaeus (1707-78), sueco que apresentou suas idéias em três obras seminais: Systema naturae fundamenta botanica (1735), Genera plantarum (1737) e Species plantarum (1753). O nome científico das plantas e dos animais é citado em Latim e obedece a uma escala hierárquica (espécie, gênero, classe e ordem). As missas e ofícios religiosos da Igreja Católica eram ministrados em Latim, mas o idioma ainda é bastante usado pela Santa Sé.

Espírito missionário. Outra característica importante era o modo como os antigos missionários encaravam o ofício religioso. Com efeito, a disciplina e a obediência hierárquica promoviam até cura, como ocorreu com Padre Vicente Rodrigues, que vivia a "lançar a alma pela boca". Ele padecia de enxaquecas por longos períodos, resultante das enfermidades tropicais e trabalho extenuante - os missionários tinham que andar longos trechos à pé e descalços, dormiam nas piores condições e estavam expostos aos caprichos do tempo. Padre Vicente desempenhava importantes funções na catequese do gentio, mas era "achacoso" e teve que obedecer a uma inusitada ordem do Padre Manoel da Nóbrega, seu superior: "- Padre Vicente, o bem das almas tem necessidade de vós; portanto vós ordeno em virtude de santa obediência, lanceis fora essa doença e vades acudir a nossos ministérios" (p. 37) 11 A ordem promoveu uma "cousa estupenda", pois Vicente se fez prontamente curado dos achaques.

Os jesuítas levavam à sério as determinações dos superiores e a obediência podia resultar até na proibição de morrer! Conta-se que o Padre Salvador Rodrigues se encontrava gravemente enfermo, em razão das febres quartãs (malária), mas ele era útil aos propósitos da Companhia e, portanto, Padre Nóbrega o proibira de morrer até o seu retorno da vila de São Vicente.

"Cartas jesuíticas I-Manoel da Nóbrega. Belo Horizonte e São Paulo: Editora Itatiaia e EDUSP, 1988. 


\section{Padre Raulino Reitz e as ciências naturais no Brasil}

O enfermo reuniu suas forças e fez de tudo para obedecer às ordens do superior, mas o seu estado físico piorou sensivelmente e Nóbrega não retornou, parecendo ter sido preso por compromissos mais relevantes. Padre Salvador mergulhou num profundo dilema existencial, pois estava se encaminhando para a quebra do compromisso de obediência. Sensibilizado por suas dores físicas e espirituais, o Padre Provincial Luiz da Grã veio em seu socorro e lhe tirou os encargos do grave compromisso; Salvador se determinou a morrer com alegria e foi o primeiro jesuíta a morrer em solo brasileiro (Bahia, 15 de Agosto;1553).

Solitude. Mentes científicas e religiosas também se assemelham num outro quesito: o ensimesmamento reflexivo ou um tipo de ruminação mental a que eles se entregam com regularidade, como atestam alguns depoimentos autobiográficos de ilustres cientistas. Com efeito, o espanhol tem uma palavra de difícil tradução para outros idiomas - solitude, que serve para designar "solidão, retiro" (Dicionário Houaiss, 2001) ou o "estado ou vida solitária; reclusão" (Webster's New Universal Unabridged Dictionary, 1996). Solitude deriva de solis, o astro-rei, e tem relação com certos conceitos psicológicos, como saudade (soledad, muitas vezes mencionado incorretamente na forma plural), solipsismo (hábito de quem é solitário e de vida reclusa) e solilóquio (falar consigo mesmo, monólogo). Solidão é vista como algo negativo ou indesejável, mas solitude é um estado emocional relacionado à contemplação, criatividade e êxtase religioso; é a ocasião em que o indivíduo mergulha em seus pensamentos e retorna com novas idéias. Poetas e romancistas conhecem esse tipo de contemplação mental, mas alguns ensaios autobiográficos revelam que os naturalistas também se incluem nesse grupo.

$O$ entomologista Edward $\mathrm{O}$. Wilson descreveu a natureza como um sonho de privacidade, controle e liberdade - its essence is captured for me by its Latin name, solitudo (WILSON, I994; p. 56). O conceito é antigo, mas pouco examinado. Com efeito, Santiago Ramón y Cajal (1852-1934), o pai da moderna neurociência, recorreu ao estado mental para explicar o processo criativo. Como seria de se esperar, pois solitude é uma palavra de seu idioma materno, ele foi mais específico ao descrevê-lo. Trata-se de um refinado estado de contemplação e saborosa sensação de liberdade - esses estados emocionais se perdem numa conversa informal, pois nossas ações e pensamentos são guiados pelo interlocutor. Ramón y Cajal despendia a maior parte do tempo debruçado sobre microscópios, pois as células e os circuitos neurais eram seus objetos de estudo, mas ele exibia a postura de um genuíno naturalista:

The admiration of nature constituted, as I have said, one of unbridled tendencies of my spirit. I never tired of contemplating the splendours of the Sun, the magic of the twilight, the alternations of vegetation, 
with its gaudy spring festivals, the mystery of the resurrection of insects, and the varied and picturesque scenery of the mountains (RAMON Y CAJAL, 1991; pp. 16-7).

Reverência à obra de Deus. O acesso a uma educação sistemática, o espírito auto-suficiente e a reverência aos elementos da natureza explicam a vocação naturalista não somente dos loyolistas, mas dos padres de modo geral. Os antigos missionários lidavam com homens rudes e incultos, mas minimizavam a frustração intelectual com relatos detalhados sobre a biodiversidade e descrições sobre os costumes do gentio. Os missionários tinham bom preparo físico e agiam como se fossem trabalhadores braçais, mas não se esqueciam que exerciam uma função especial. Eles desenvolveram técnicas de agricultura, construíram vilas e escreveram obras científicas. Um dos pioneiros das ciências naturais no Brasil é Frei José Mariano da Conceição Velloso (1742-1811), o qual se destacou na botânica, zoologia e química.

Os reflexos dessa somatória ainda são constatáveis nas obras de alguns religiosos que se fixaram no Sul do Brasil, como os padres Pio Buck, João Alfredo Rohr e Balduíno Rambo. A conduta científica e a devoção religiosa guardam certas afinidades, principalmente no que diz respeito ao espírito reflexivo (solitude) e reverência à natureza. Os comentários de Ramón y Cajal permitem ver mais semelhanças que diferenças, mas Raulino Reitz também caminhou nessa direção: ao explicar como surgiu o seu interesse pelas plantas, ele disse: " $-\mathrm{E}$ vendo Deus na natureza e admirando nela os reflexos da perfeição divina é que decidi dar início a este herbário" (In: BERNARDES, 1996; p. 5).

\section{A infância de Raulino no Louro}

Padre Raulino é herdeiro da tradição que associava a formação religiosa, valorização do trabalho árduo e reverência aos elementos da natureza. Ele deu importantes contribuições ao desenvolvimento da botânica e seus discípulos se encontram espalhados em vários campos do conhecimento, com atuação no Brasil inteiro. Como educador e humanista, ele foi responsável pela formação de ilustres personagens da vida catarinense. Reitz nasceu em Antonio Carlos, município vizinho de Florianópolis, em 19 de Setembro/1910 e faleceu em 20 de Novembro/1990, aos 71 anos de idade. Ele era filho de Nicolau Adão Reitz e de D. Ana Wilvert Reitz, descendentes diretos dos primeiros colonos alemães que, por volta de 1830, fundaram uma colônia no Alto Biguaçu e Santa Bárbara. A colônia era conhecida como "Comunidade do Louro" em razão do rio homônimo, o qual por sua vez fora assim designado devido a um frondoso tronco de louro (Cordia trichotoma) caído sobre suas margens e que servia de ponte aos moradores. 
A comunidade do Louro ganhou importância em razão dos esforços de seus moradores, pois o sistema de comunicação com a capital era precário e a geomorfologia da região era acidentada; o suor dos colonos embebeu o solo e as primeiras colheitas serviram para saciar a fome dos pioneiros, são as palavras do Padre Raulino (1988). Os irmãos mais velhos ou adultos mais capacitados se encarregavam de ensinar às crianças o $\mathrm{ABC}$ e os rudimentos de Aritmética, mas logo surgiram os professores ambulantes. Eles permaneciam um ou dois anos na comunidade e recebiam um ou dois mil réis mensais, mais algumas regalias concedidas pelos moradores. Um desses professores foi Fernando Knoll (1866-1958), poeta e possuidor de dons musicais. Outro profissional muito requisitado era o dentista ambulante, o terror da meninada. Eles visitavam várias regiões e os intervalos entre as visitas eram longos, muitos anos. A broca e os boticões vinham no alforje das mulas, mais uma cadeirinha. Os anestésicos não existiam ou eram pouco eficazes, de modo que eles tinham que extrair o dente cariado com rapidez e eficiência. As crianças não dormiam só em saber que esses profissionais estavam atuando nas cercanias, pois o tratamento odontológico praticamente se resumia na extração do dente cariado.

Outros profissionais que atuavam no Louro eram as benzedeiras e os conhecedores de mezinhas e beberagens. Os habitantes eram atormentados por doenças variadas (e.g., infestações parasitárias, malária e febre amarela), mas terapêutica recomendada geralmente se restringia ao "suadouro", ingestão de óleos laxantes e beberagens domésticas; os casos mais difíceis ou insolúveis eram entregues às benzedeiras, as quais usufruíam bom conceito junto a algum santo e usava o prestígio para obtenção de uma graça em favor dos enfermos. Quando os remédios naturais e espirituais não surtiam o efeito desejado, o enfermo era entregue à própria sorte. As mulheres que davam à luz contavam com a assistência das parteiras, como as valorosas Anastásia Guesser e Maria Platten; as "cegonheiras" ofereciam conforto emocional às mulheres aflitas e usavam suas habilidades para trazerem os bebês ao mundo. Não havia qualquer tipo de remuneração. Frau Maria Platten veio da Alemanha com os pais, casoul-se com o escravo Miguel Ferreira (houve muita miscigenação no Louro) e deixou uma numerosa descendência; ela exerceu a profissão por mais de 40 anos - estima-se que através de suas mãos mais de mil bebês foram partejados, inclusive o bebê Raulino!

A comunidade do Louro era um caldeirão étnico, pois foi o lar de famílias alemãs, açorianas, libanesas e dos africanos trazidos de Angola. A região também era habitado por índios da etnia Xokleng, os quais andavam nus e pouco se relacionavam com os colonos, mas roubavam galinhas e davam prejuízos aos plantadores de milho e mandioca; para evitar confusões, algumas familias penduravam certos produtos da lavoura nas árvores, os quais eram recolhidos às escondidas pelos índios. 
Informações úteis sobre a região podem ser obtidas nas obras do Padre Raulino (REITZ, 1988; 1992), mas uma entrevista com o Sr. Natalício Antonio Custódio acrescentou novos elementos acerca do cotidiano dos antigos colonos que deram vida ao Louro.

Seu Ticula, como ele é conhecido pelos inúmeros amigos, é um cidadão que se encontra às portas dos 90 anos de idade e é membro da laboriosa comunidade negra de Antonio Carlos (nome atual da região), onde viveu praticamente toda a sua vida. Ele estudou até o $3^{\circ}$ ano primário, pois os trabalhos na lavoura o impediam de freqüentar regularmente a escola, e somente aos 16 anos de idade teve oportunidade de calçar um par de sapatos. Não obstante essas dificuldades, ele chegou a ser dono de serraria e amealhou recursos para a compra de um caminhão FNM (fenemê, como era conhecido pelos antigos) e dirigia com uma autorização especial concedida pelo delegado de polícia; a idade parece não lhe pesar nas costas, pois Ticula é dono de boa conversa e usa a bicicleta para atender aos compromissos na comunidade. Trata-se de uma fonte importante, pois o referido cidadão conheceu pessoalmente Raulino e seus irmãos - ele chegou a ser batizado pelo mais velho, Padre João Reitz - e a história de sua vida se confunde com a do município Antonio Carlos.

Antonio Carlos é o principal fornecedor de frutas, hortaliças e legumes da capital, mas desde os primórdios de sua existência que o município é produtor de farinha de mandioca, açúcar grosso (mascavo) e melado, cachaça, laticínios e outros produtos de origem animal. Os produtos e commodities eram transportados nas "chatas", embarcações de tamanho variável ( $9 \mathrm{~m}$ de comprimento) e cuja designação dá uma idéia sobre o seu formato ajangadado; elas eram feitas com madeira nobre, como cedro e peroba. As chatas transportavam até 60 sacas de farinha ou três pipas de cachaça e percorriam o rio Biguaçu até à capital. O percurso de ida exigia perícia e muita atenção, em razão do fluxo da correnteza, mas dois empurradores negros tinham que usar seus músculos para impulsionar as chatas rio acima; isso era feito com duas enormes varas de bambu e o monótono e cansativo processo demorava quase um dia inteiro. Um dos capitães de chata foi o Sr. Antonio José Custódio, pai de Seu Ticula, e não é exagero dizer que muito do progresso do Alto Biguaçu se deve aos seus músculos.

Outra forma engenhosa de transporte de cachaça foi inventada pelo $\mathrm{Sr}$. Dominik Reitz, parente de Raulino. Em 1942, o produto tinha atingido boa cotação no mercado, de modo que, por quatro vezes seguidas, ele resolveu lançar nas águas do Rio Biguaçu os barris contendo o produto. Ele contratou alguns trabalhadores para acompanhar o percurso dos barris, mas o único trabalho que eles tinham era remover a carga que se prendia nos galhos das árvores ou ficava retida nas tranqueiras do rio. Dentre 400 barris lançados ao rio, 
somente três se perderam e, mais tarde, descobriu-se que eles foram roubados pelos apreciadores da boa cachaça da região. A forma de transporte era segura e econômica, mas o desenrolar da II Guerra Mundial prejudicou as exportações e paralisou a produção dos alambiques.

As mercadorias também eram transportadas em carros de boi ("cabeça de boi"), mas tudo dependia das condições das estradas. As viagens eram mais demoradas e exigiam cuidados redobrados, pois as estradas não eram pavimentadas e as chuvas praticamente inviabilizavam os deslocamentos tropeiros e as alimárias corriam o risco de ficarem atolados nos lamaçais! Atualmente, as viagens de automóvel de Antonio Carlos a Florianópolis não consome mais que $40 \mathrm{~min}$, mas Seu Ticula nos informou que os produtores levavam quase um dia inteiro para terem acesso aos consumidores da capital. Era uma verdadeira epopéia. Os moradores viajavam à cavalo ou transportavam cargas mais leves e crianças nas carroças, mas as viagens eram demoradas e igualmente desconfortáveis.

A tração animal também era útil na aragem do solo e no funcionamento dos engenhos de farinha e açúcar. A região do Alto Biguaçu era um importante fornecedor de produtos agropecuários e fornecia madeira para a capital, principalmente na ocasião da construção da ponte Hercílio Luz. As toras eram puxadas por juntas de bois e muita madeira nobre (peroba e canela) foi utilizada para revestir o piso da ponte. Seu Ticula trabalhou no corte de árvores e nas serrarias, pois havia uma demanda enorme pelo produto. Se o transporte das sacas de farinha nas chatas era algo demorado e cansativo, imagine as toras sendo arrastadas por juntas de bois... Raulino Reitz é filho desse caldeirão multi-étnico, o qual se transformou no município Antonio Carlos.

\section{A formação intelectual de Raulino}

O jovem Raulino iniciou seus estudos na Escola Mista do Louro (1927); ele caminhava cerca de $2 \mathrm{~km}$ com uma bolsa contendo a pedra (lousa preta usada para os rudimentos da escrita) e o saboroso e saudável lanche matinal (pâo de milho com queijo e melado). Os relatos biográficos descrevem que ele e irmão Afonso eram traquinas, mas a Profa. Delminda Simas Simão domava os indóceis alunos da pequena escola da comunidade. Ela era rigorosa e aplicava castigos variados, como puxões de orelha, varadas na barriga da perna ou o ajoelhar-se sobre areia grossa; a mãe lhe dava o apoio necessário, pois, da cozinha, gritava "dá-lhe mais!". Delminda exagerava nos castigos, mas não se descuidava do ensino propriamente dito. 
Os castigos físicos eram comuns no antigo sistema escolar e os educadores tinham muita preocupação com a ordem e a disciplina, algo ainda mais acentuado nas escolas das colônias alemãs. Raulino e Afonso, o qual vivia a espantar a alimária nos pastos, conheciam bem as modalidades do arsenal pedagógico, mas os alunos encontram certo refrigério nas aulas da Profa. Alvina Freiberger (1928-31), a qual havia se formado no Colégio Sagrado Coração de Jesus, na capital, e tinha mais jeito com as crianças; ela promovia festinhas, envolvia os alunos em representações teatrais e convidava os pais para os eventos - é o nascimento da moderna pedagogia no Louro! Raulino e Afonso eram traquinas, mas as traquinagens eram coisas de crianças e não revelavam nenhum desapego à vida escolar. Os estudos de ambos nunca foram interrompidos e, com efeito, o jovem Raulino tinha como padrinho Pedro Amâncio Konrad, conhecido professor de Rachadel, povoado próximo do Louro.

Os avanços nos estudos e a tradição religiosa da família induzem Afonso e João Reitz a se decidirem pela vida sacerdotal, opção que acaba influenciando Raulino, o mais novo dos três irmãos. Com efeito, em 1932 ele ingressa no Seminário Menor de Azambuja, em Brusque/SC. O recém-sacerdote João lecionava ali e na ocasião presenteou o irmão com o Dicionário etymológico, prosódico e orthographico da língua portuguesa (1928), de J.P. da Silva Bastos. O presente vinha com uma significativa dedicatória: "Meu caro Raulino, tens em tuas mãos um tesouro de imenso valor, porém oculto. Trata de explorá-lo com constância, com livro à mão e a pena em punho. Teu irmão que te quer". O tesouro foi de grande serventia e acompanhou Raulino a vida.

A permanência no Seminário de Azambuja (1932-36) The proporcionou uma boa formação acadêmica e fortaleceu o amor à Igreja Católica. Após a conclusão do curso Ginasial e Clássico (equivalentes aos $1^{\circ} \mathrm{e} 2^{\circ}$ Graus), Raulino ingressa no Seminário Central de São Leopoldo/RS, onde conclui os cursos seminarísticos de Filosofia e Teologia (1937-43). A opção pela vida sacerdotal se clareou na mente do amadurecido Raulino e foi em S. Leopoldo que ele teve os primeiros contatos com padres naturalistas, como João Evangelista Rick (1869-1946), Pio Buck (1883-1972) e Balduíno Rambo (1905-61).

Padre Buck era suíço de nascimento e dirigia o Museu Anchieta de Ciências Naturais, do Colégio Anchieta de Porto Alegre/RS, onde se dedicava com especial interesse à entomologia e botânica. Ele também era o capelão da penitenciária da capital gaúcha e figura conhecida por seu trabalho missionário junto aos apenados. Brincalhão e dono de um humor peculiar, às vezes ele dizia: "Nunca diga que conhece o Padre Pio, pois eu passei 43 anos na cadeia" - como capelão, é claro (Diário de Santa Maria, 18 de Junho/2010). Além dos compromissos de natureza espiritual, ele encontrava tempo para produzir chás medicinais, os quais eram gentilmente oferecidos aos presos. Padre Buck estudava as plantas, catalogava as espécies e buscava informações sobre suas propriedades terapêuticas. 
Certa ocasião, o jovem Raulino é convocado a participar dessas atividades; ele é designado a coletar plantas variadas para compor os chás e, então, começa a germinar a sua paixão pela Botânica: ele aprende o processo de herborização, investiga a nomenclatura científica e dá início a uma pequena biblioteca especializada nesses assuntos (BESEN, 1992; BERNARDES, 1996).

O relacionamento com Padre Rambo também foi produtivo, pois Raulino recebeu orientações e estímulos para dar prosseguimento aos estudos em Botânica, a paixão de sua vida. De acordo com os relatos do Padre Besen (1992), amigo e conterrâneo, as coletas do Padre Raulino tiveram início no primeiro ano do curso de Filosofia (1937) e duraram a vida toda. Em Abril/1938, ele freqüentava o segundo ano no Seminário de São Leopoldo/RS quando herborizou a sua primeira planta, uma avenca (Adiantopsis chlorophylla). As coletas e herborizações duraram mais de meio século! O precioso material era guardado em caixas de papelão e serviram para compor as coleções do futuro Herbário Barbosa Rodrigues. O jovem seminarista contava 23 anos de idade, mas já tinha em mente um projeto grandioso de vida.

Ao finalizar os estudos no Seminário Central, Raulino solicita (22 de Junho/1942) a Dom Joaquim Domingues de Oliveira (1878-1967) a ordenação de subdiácono e, num curto espaço de 20 dias, ele recebe três ordenações: Subdiaconato (15 de Agosto/1943), Diaconato (29 de Agosto/1943) e Presbiterado ( 5 de Setembro/1943). Faltavam 15 dias para a idade canônica (24 anos), mas Raulino fora dispensado do requisito, pois $\mathrm{D}$. Joaquim necessitava nomear o mais rapidamente possível um padre auxiliar para a Paróquia de Turvo. Nos quatro anos seguintes, ele é designado Vigário Paroquial nas cidades de Turvo (10 de Setembro/1943 a 25 de Janeiro/1944), Sombrio (25 de Janeiro/1944 a 12 de Janeiro/1946), Itajaí ( 12 de Janeiro a 25 de Novembro/1946), Orleans (25 de Outubro/1946 a 11 de Janeiro/1947).

Os habitantes do Louro viviam quase isolados, mas o primeiro filho da terra a cursar uma universidade foi o Cônego João Adão Reitz (1904-84), irmão mais velho de Raulino que ingressara na Universidade Gregoriana (Roma, 1925) para cursar Filosofia e Teologia - a Rodovia SC 408, que liga o município de Antonio Carlos a Biguaçu, leva o nome João Adão Reitz, mas é uma referência ao avô que viera da Alemanha e se instalara na região (1842-1940). Raulino não ficou atrás na formação acadêmica, pois ele realizou estudos especializados na Iowa State University (Tecnologia de Madeira e Microtécnica Botânica, 1955), foi designado Cônego Honorário do Cabido Metropolitano (1966) e defendeu tese de doutoramento em Botânica Sistemática na UNICAMP (1973) - o primeiro filho da antiga comunidade do Louro a atingir tal distinção. Padre Raulino foi membro associado da Academia Brasileira de Ciências e de outras instituições científicas espalhadas pelo mundo. 
O incansável catarinense também desempenhou importantes missões junto ao governo estadual, como a vice-presidência da Fundação de Amparo à Tecnologia e ao Meio Ambiente (FATMA, 1976-79) e direção do Parque Botânico do Morro do Baú (REIS, 1992). Padre Raulino era respeitado pelos especialistas do mundo inteiro e chegou a assumir a direção do Jardim Botânico do Rio de Janeiro (1971-75), perfilando-se ao lado de ilustres naturalistas que o precederam. Essas atividades se somam às funções sacerdotais, mas ele também nunca se descuidou da edição da revista Sellowia, da administração do Herbário Barbosa Rodrigues e da publicação de suas pesquisas.

\section{O retorno ao Seminário de Azambuja}

Outra experiência marcante na vida do Padre Raulino foi o retorno ao Seminário Menor Metropolitano de Azambuja (11 de Janeiro/1947 a 14 de Maio/ 1971). Ele cursara o Colegial na instituição e a ela retorna para assumir as funções de professor e Diretor de Ensino. O período de atuação coincide com a época áurea do seminário, pois a qualidade do ensino estava no mesmo nível das melhores instituições de ensino, de Santa Catarina e demais estados da federação. Raulino empolgava seus alunos, o ensino era artesanal e ele conciliava os ensinamentos teóricos com aulas práticas. Isso é fortemente recomendado nos dias atuais, mas era algo rotineiro em Azambuja. Ele era um mestre desdobrável, pois ministrava aulas de Latim, Inglês, Alemão e Espanhol, conduzia pessoalmente os alunos ao campo, onde eles tinham aulas de agronomia, geologia e astronomia; os temas eram variados, mas Raulino também se desdobrava nas aulas de Anatomia, Fisiologia e História do Brasil e das Américas. O ensino nos seminários era conduzido com muita seriedade, o que torna ainda mais meritório esses esforços do Padre Raulino. Após tudo isso, ele ainda encontrava tempo e energia para se dedicar às pesquisas originais.

$O$ interesse científico era maior quando se tratava das plantas e dos animais, mas Padre Raulino também se interessava por observação de fenômenos astronômicos e, com efeito, por mais de 20 anos ele esteve à frente da disciplina Cosmografia. Muitos alunos sequer sabem o assunto tratado pela disciplina, mas, em noites plenilunares, os jovens seminaristas tinham aulas ao ar livre sobre a história do Universo; eles despendiam algum tempo observando as crateras da Lua, discutiam as teorias sobre a formação dos planetas e registravam a localização das principais constelações, nebulosas e estrelas. $\mathrm{O}$ entusiasmo do Padre Raulino contaminava os alunos, mas eles tinham que usar a imaginação para associar o amontoado de pontinhos luminosos à figura de um escorpião! Essas informações foram relatadas pelo Padre Artulino Besen (1992), o amigo de infância que nos deixou algumas notas biográficas sobre o ilustre naturalista catarinense. 


\section{Padre Raulino Reitz e as ciências naturais no Brasil}

Padre Raulino era um professor compenetrado e valorizava a disciplina, mas era sensível em relação às dificuldades dos alunos - era hard worker, mas não exigia dos alunos aquilo que ele impunha a si mesmo. Ele foi importante para a formação de vários alunos, os quais atualmente desempenham importantes funções na sociedade catarinense (e.g., professores, juízes, políticos e intelectuais de matizes variadas). Seus superiores conviviam bem com suas extravagâncias e idiossincrasias, pois entendiam que elas tornavam os assuntos mais interessantes e engrandeciam a formação dos seminaristas. As aulas eram programadas para o início da semana, de forma a permitir tempo livre para as pesquisas de Quinta-feira a Domingo. O privilégio contava com o apoio e consentimento de D. Joaquim, pois o arcebispo sempre encontrava uma solução para compatibilizar as responsabilidades pedagógicas e as viagens do Padre Raulino.

De modo geral, a estrutura de ensino exigia muito dos professores e dos alunos, pois se tinha em mente a qualidade da formação dos futuros sacerdotes. Trata-se de um horrível truísmo, mas a afirmação tem significado especial no ensino religioso. O reitor prestava muito atenção no desempenho dos alunos e o ensino não era impessoal, distante e massificado como nos tempos atuais. O Diretor de Ensino devia prestar contas à comunidade, diante do Reitor e do Arcebispo Metropolitano. A lista dos alunos reprovados era enviada ao Reitor no dia 7 de Dezembro de cada ano e era lida ao meio-dia no refeitório, o que deixava muitos alunos "fracos das pernas"; não havia preparo para o anúncio das tristes notícias. No dia seguinte, numa sessão solene que contava com a participação do Reitor e do Arcebispo Metropolitano, realizava-se a leitura das notas dos alunos aprovados.

As notas eram anunciadas em Latim e o Arcebispo tinha os olhos e os ouvidos atentos aos três primeiros colocados, as jóias preciosas do futuro sacerdócio. Quando a pontuação média da turma caía, D. Joaquim escrevia uma carta do próprio punho para alertar o Reitor acerca da queda de desempenho. Esses procedimentos revelam a preocupação dos dirigentes acerca da formação intelectual dos sacerdotes, os quais diferem muito dos atuais procedimentos adotados pelas escolas: ensino descuidado, excessivamente teórico e mais voltado para as tagarelices. Tudo deve ser de acordo com a "realidade brasileira" e o objetivo é empurrar os alunos para os títulos formais, não prover-lhes de conhecimentos universais ou a formação intelectual do cidadão. É uma calamidade.

Essas notas preliminares suscitam certas dúvidas no leitor atento: Raulino Reitz era um sacerdote ou era um cientista? Como ele compatibilizava essas duas atividades? Ele era darwinista? Antes de tudo, é importante ressaltar que Padre Raulino era apaixonado pelas coisas da ciência, mas não se descuidava de sua missão sacerdotal. O elevado conceito usufruído junto aos 
seus superiores e o seu prestígio na comunidade acadêmica provam que ele soube compatibilizar suas responsabilidades sacerdotais e as inquietudes de um pesquisador original; ele se destacou em todas as funções assumidas.

No que diz respeito à teoria sobre a origem da vida, formulada por Charles R. Darwin (1859), nós temos apenas indícios de que Raulino Reitz convivia ou aceitava bem as postulações do naturalista inglês. O depoimento de Ademir Reis, ex-seminarista que exerceu atividades de monitoria junto ao estimado mestre, reforça essa conclusão. Além disso, ele respeitava as idéias de Fritz Müller e chegou a resgatar alguns de seus documentos que se encontravam espalhados na Alemanha; como sabemos, Müller era um ardoroso defensor da teoria da seleção natural. Os setores mais conservadores da Igreja Católica não viam com bons olhos o darwinismo, mas as animosidades diminuíram com o tempo. Teorias científicas são instrumentos úteis aos avanços do conhecimento, mas não são verdades cristalizadas ou definitivas. Padre Raulino não deixou nenhum relato específico sobre o assunto e tampouco percebemos os sinais de alguma crise espiritual ao longo de sua trajetória acadêmica e religiosa. Ele era dotado de inteligência excepcional e, portanto, é natural que tivesse uma compreensão mais sofisticada sobre o livro Gênesis, bem como acerca das teorias sobre a origem da vida. Infelizmente, só podemos trilhar os caminhos da especulação, pois a mente científica é mais recheada de dúvidas e indagações que respostas definitivas.

\section{As andanças de Raulino}

Balduíno Rambo, João Alfredo Rohr e Raulino Reitz pertencem à tríade dos sacerdotes jesuítas que deram importantes contribuições às ciências naturais. Além da ligação com a região Sul, mais especificamente com o Estado de Santa Catarina, eles tinham ascendência germânica e eram possuidores de sobrenomes curtos e sonoros, todos se iniciando com a letra $\mathrm{R}$. O último deles era conhecido como "o padre dos gravatás"; o título é simpático e afetuoso e ele próprio parecia gostar da distinção, embora ela tenha o inconveniente de suscitar sentimentos românticos ou dá impressão que a vida de um naturalista seja doce e prazerosa, quando na verdade é o oposto. A formação intelectual de Raulino Reitz foi uma feliz conjugação das inquietudes de um homem do interior, a herança familiar germânica, que tanto é apegada aos encantos da natureza, e a disciplina da vida religiosa.

Ele exibia certos atributos que caracterizam a personalidade de um homem empreendedor. Enquanto uns vêem as dificuldades como obstáculos intransponíveis, os espíritos arrojados encaram os desafios como estímulos para a ação. 
Essas pessoas exercem liderança espontânea, pois suas idéias e ações mobilizam os circunstantes, como a força gravitacional exercida pelos corpos estelares sobre os planetas. Padre Raulino usou o seu prestígio e suas habilidades em beneficio das ciências naturais e deixou marcas institucionais, como o Herbário Barbosa Rodrigues e criação do periódico Sellowia; seus ex-colaboradores nunca deixam de reverenciar a memória do mestre.

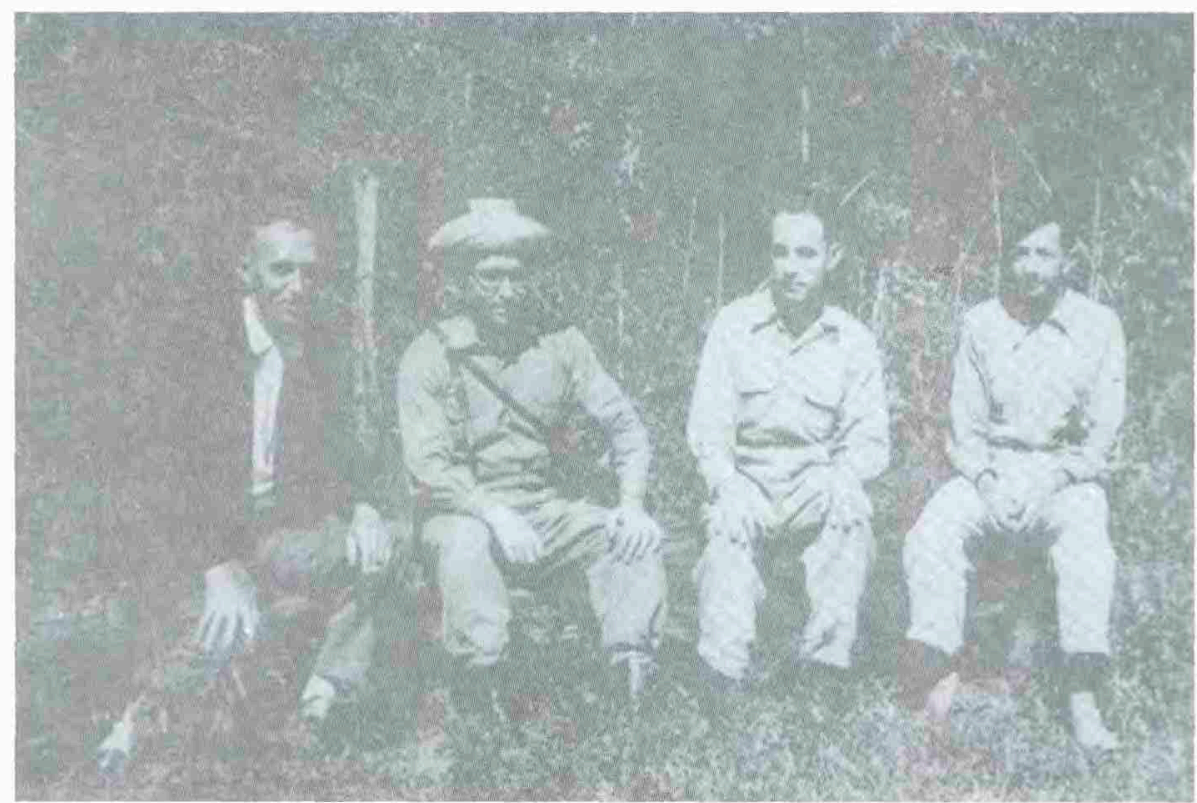

Figura 2

O descanso dos membros de uma expedição científica (Morro do Baú, Município de Ilhota/SC). Os dois no centro são Raulino Reitz (de chapéu) e Roberto M. Klein.

Um colaborador próximo e também pioneiro da botânica na região Sul foi Roberto Miguel Klein (1923-92). Ele atuou como Diretor do Herbário Barbosa Rodrigues e foi professor do. Departamento de Biologia, da UFSC, onde teve oportunidade de influenciar os rumos da vida acadêmica de alguns discípulos. Klein é natural de Montenegro, município do Rio Grande do Sul; ele fora seminarista, mas desistiu do sacerdócio. Em 1949, Padre Raulino estava iniciando um levantamento da flora catarinense e Klein o procurou para se integrar ao projeto. As coisas estavam ainda num estágio preliminar e, portanto, a parceria teve que ser postergada. Enquanto isso, Klein passou a atuar como locutor de rádio no município de Estrela/RS, pois, além de possuir boa voz, ele era fluente em alemão e o programa Hora Alemã era inteiramente direcionado à colônia. 
O contrato tinha dois anos de duração e, ao final, Klein novamente procura o Padre Raulino, que o recomenda a buscar a orientação de Henrique Pimenta Velloso (1917-2003). A construção do herbário não estava concluída, mas Klein poderia se integrar à equipe do Dr. Velloso, o qual estava realizando um levantamento fitoecológico em Santa Catarina, tendo como objetivo relacionar a presença das bromélias com a proliferação dos mosquitos anofelinos (DESCHAMPS \& SALERNO, 1998).

O projeto liderado pelo Dr. Velloso tinha como objetivo o combate aos mosquitos anofelinos e erradicação da malária em Santa Catarina. Atendendo à recomendação de Raulino, Klein se integra ao serviço de malariologia (Brusque/SC); os dois tinham interesses confluentes e a parceria logo teve início a partir da transferência do herbário do Rio Grande do Sul para o Seminário de Brusque (1949-54) e, em seguida, para um prédio próprio construído em Itajaíl SC. Entretanto, as mudanças de rumo trouxeram novos desafios à Klein, tanto no setor de malariologia quanto no herbário. Ele havia cursado Filosofia no seminário e, para validar suas funções, ele é forçado a cursar História Natural. Com muitas dificuldades e incontáveis viagens, ele conclui o curso na Universidade Federal do Paraná (1960-64).

Outro problema era a própria sobrevivência. A remuneração era insuficiente até mesmo para os hábitos espartanos de um ex-seminarista e, assim sendo, Klein é forçado a conciliar as pesquisas de botânica com aulas na UFSC (só atuou em 1964) e, mais tarde, nas instituições de ensino que hoje são conhecidas como UNIVALI e FURB. No início da década de 1970, ele busca um curso de pós-graduação na Universidade de São Paulo, mas se depara com outro problemão. Ele tinha como objetivo iniciar o Mestrado (1972), mas a qualidade de suas pesquisas o conduziu diretamente ao Doutoramento; a tese é concluída em 1977, mas defendida em 1979, em razão da falta de credenciamento do recém-criado curso. Antes de completar 70 anos, Roberto Klein sobre um acidente vascular cerebral e falece pouco tempo depois (13 de Novembro/1992). Desafortunadamente, a inteligência catarinense perde duas lideranças científicas num curto espaço de tempo, pois Raulino havia falecido no final de 1990.

As ciências naturais avançavam graças ao suor e aos músculos dos pioneiros. Raulino e seus colaboradores viajavam longos percursos para coletar material e não se amedrontavam com as flutuações climáticas e características do ambiente; as coletas eram feitas nas serras e nos banhados, com tempo bom ou tempo ruim. Os deslocamentos eram feitos em Jipe, motocicletas, barcos, lombo de cavalo ou a pé. Esse tipo de atividade exige disciplina, bom preparo físico e coragem diante das adversidades; no meio do mato e longe da civilização, o homem se encontra consigo mesmo. Ao anoitecer, surgem visitantes estranhos, os insetos hematófagos não dão sossego e os sons emitidos pelas alimárias assustam até aos mais corajosos. 
As oscilações climáticas acentuam os desconfortos e as noites nas matas estão bem longe do cenário edênico do noble sauvage. Alualmente, os naturalistas contam com notáveis recursos tecnológicos e existem poucas regiões inexploradas, diferentemente das dificuldades enfrentadas pelos desbravadores.

\section{Ciências naturais e a verdadeira descoberta do Brasil}

O final do século 19 é marcado por eventos de grande importância na história do Brasil, como a libertação dos escravos (13 de Maio/1888) e a Proclamação da República (15 de Novembro/1889). O momento também é marcado pelos relatos dos desbravadores brasileiros que se adentraram pelos sertões e nos ofereceram descrições mais realistas sobre o país. Os visitantes estrangeiros despendiam pouco tempo no Brasil, não conheciam a língua dos nativos e vinham com a cabeça cheia de crendices da época. Isso explica os relatos sobre as guerreiras amazonas, cobras que engoliam um boi inteiro e a profusão de tribos de antropófagos. Frei Vicente do Salvador dizia que os portugueses "caranguejavam" as costas do Brasil, mas é verdade que o interior do país ficou por ser "descoberto" até o início do século 20. É o momento em que os desbravadores se enveredam pelos sertões e nos oferecem relatórios mais precisos.

A obra do General J.V. Couto de Magalhães (1837-98) descreve os costumes dos índios e os traços geomorfológicos do sertão brasileiro. O Marechal Candido Rondon (1865-1958) também discute os hábitos dos indígenas, mas se detêm mais nos aspectos demográficos e sanitários das regiões visitadas (Mato Grosso e Amazônia). Interessante é examinar a opinião desses dois sertanistas acerca dos hábitos antropófagos dos índios brasileiros. O mito surgiu a partir das invencionices dos exploradores estrangeiros, mas a prosa cativante de Michel de Montaigne (1533-92) também contribuiu para a sua consolidação - ele nunca pisou em solo americano, mas discorreu longamente sobre os hábitos dos índios "comedores de gente". Interessantemente, as cartas jesuíticas do Padre Manoel da Nóbrega (1517-70) informam em vários momentos que o abominável hábito antropofágico fora eliminado havia muito tempo e que os próprios nativos tomavam como injúria a simples busca de informações acerca do assunto. Entretanto, as fontes mais confiáveis sobre o assunto são os depoimentos do General Couto de Magalhães e do Marechal Rondon, pois eles conheciam bem os nativos e tiveram oportunidade de descobrir tribos desconhecidas. Os dois sertanistas despenderam muitos anos entre a indiada e conheciam seus costumes, mas exibiam opiniões divergentes sobre a antropofagia: pura invencionice ou histórias contadas para explicar o desaparecimento de naturalistas nas selvas amazônicas. Couto de Magalhães é mais específico sobre o assunto: 
Viajei, como já disse, o Brasil de Nascente a Poente, de Norte a Sul, em toda a sua extensão; vivi anos nos sertões do Araguaia, no centro dos selvagens de Goiás, Mato Grosso e Pará; falo corretamente a língua mais geral entre eles, que é o tupi, tinha interpretes para outras, pois fundei lá um colégio de língua, sob proteção da Princesa D. Isabel, e nunca encontrei e nunca soube de uma só tribo de antropófagos! (p. 150) ${ }^{12}$

As expedições científicas eram realizadas com propósitos específicos, mas trouxeram informações valiosas sobre os recursos naturais e condições de vida do homem do interior. Um exemplo foi o relatório elaborado pelo engenheiro belga Luiz Cruls (1848-1905) ${ }^{13}$, o qual fora designado a explorar o Planalto Central para determinar o melhor local para instalação da futura capital da república. O relatório Cruls (1894) descreve os elementos da fauna e da flora, bem como as doenças mais comuns dos habitantes dos grotões do Brasil. Esses documentos contrastam enormemente com a imagem poética paradisíaca que emergia na obra de alguns poetas e romancistas, mas o choque maior veio com o relatório da expedição liderada por Arthur Neiva e Belisário Penna (1916), médicos sanitaristas do Instituto Oswaldo Cruz.

O longo relatório de Neiva e Penna foi publicado em formato de paper (texto de 151 páginas e 116 fotografias de papudos, opilados e deficientes físi$\cos$ ) e foi o resultado das expedições aos estados do Nordeste e Centro-Oeste, regiões completamente desassistidas do poder público. Eles denunciaram as condições sanitárias deploráveis e as enfermidades que atormentavam os habitantes dos grotões do Brasil: doença de Chagas, tuberculose, hanseníase, sífilis e bócio. Tais enfermidades eram comuns e eram agravadas por infestações parasitárias e déficits nutricionais ${ }^{14}$. As mentes mais esclarecidas sabiam que a vida no interior era difícil, mas o relatório de Neiva e Penna revelou que o cenário era ainda pior. Num célebre discurso proferido na Faculdade de Medicina do Rio de Janeiro, o médico Miguel Pereira (1871-1918) declarou que o Brasil era um "vasto hospital".

Neiva e Penna também denunciaram a existência de um bom número de indivíduos de baixa estatura no Nordeste do Brasil; havia a suspeita de que a região estava dando origem a uma raça de anões, o "homem gabiru",

\footnotetext{
12 General Couto de Magalhães. O selvagem. Belo Horizonte e São Paulo: Editora Itatiaia, 1975. Ver também: Marechal Candido M. Rondon Apontamentos sobre os trabalhos realizados pela comissão de linhas estrutégias de Mato Grosso ao Amazonas, sob direção do Coronel de Engenharia Candido Mariano da Silva Rondon, de 1907-1915. Brasília: Senado Federal, 2003.

${ }^{13}$ Relatório Cruls - Comissão Exploradora do Planalto Central do Brasil. Brasília: Edições do Senado Federal, 2003.

1+ Viagem científica pelo norte da Bahia, sudeste de Pernambuco, sul do Piauí e do norte a sul de Goiás. Memórias do Instituto Oswaldo Cruz, 8:74-224, 1916.
} 
embora o próprio relatório já permitia entender que a diminuição da estatura era resultante de uma equação desfavorável: déficit nutricional e trabalho extenuante. O nordestino trabalhava arduamente na lavoura de cana de açúcar e se alimentava de banana e um mingau de água e farinha; ele raramente consumia carne, pois o suprimento protéico era quase exclusivamente dependente da captura de animais silvestres (e.g., tatus, preás e lagartos). A grave situação do "homem gabiru" é antiga e pouco mudou até o final da década de 1970 (Veja, 10 de Setembro/1998).

Alguns intelectuais imaginavam que o progresso nacional viria com implantações de reformas constitucionais ou até mesmo, como havia sido proposto pelo poeta Olavo Bilac (1865-1918), com o envolvimento dos jovens num projeto de militarização do país, mas o Relatório Neiva e Penna apontou que o melhor seria a construção de latrinas e fornecimento de vermífugos à população. É interessante examinar como os relatos sobre o "Brasil real" influenciaram o surgimento de um novo tipo de literatura, como os livros de J.B. Monteiro Lobato (Urupês, 1918) e J. Guimarães Rosa (Sagarana, 1946), os quais descrevem o fraco e indolente Jeca Tatu e os efeitos perversos da malária. Esse tipo de realismo literário foi inaugurado por Euclydes da Cunha (Os sertões, 1901), a qual descreve de forma quase jornalística a vida dos sertanejos que se reuniram em torno do celerado Antonio Conselheiro. O homem do interior era inculto e refratário à civilização, mas a incivilidade era ocasionada pelas doenças parasitárias e condições degradantes de vida. O sertanejo emerge da obra de Euclydes da Cunha como um tipo lombrosiano e vítima do fanatismo religioso, enquanto que para Monteiro Lobato ele é apenas um doente crônico.

\section{A erradicação da malária em Santa Catarina}

O déficit protéico e as infestações parasitárias eram problemas graves, mas as enfermidades tropicais também se somavam para tornar a vida ainda mais difícil do sertanejo. A malária é uma doença ocasionada pelas picadas das fêmeas de mosquitos do gênero Anopheles. Existem quatro espécies de protozoários que provocam a doença, os quais pertencem ao gênero Plasmodium e provocam sintomas específicos: Plasmodium vivax e $P$. ovale (manifestação dos sintomas em dias alternados), $P$. malariae (manifestação dos sintomas a cada três dias, associados ao enlargamento do baço) e $P$. falciparum (a forma mais grave, pois os sintomas se manifestam continuamente e estão associados a outras complicações). Ao picar uma pessoa doente, uma das formas do protozoário é transferida para o sistema digestivo do inseto, onde amadurece e é transferido a outra pessoa no momento de uma nova picada. Esse é o ciclo evolutivo do agente transmissor da malária. Ao se instalar no organismo de uma pessoa saudável, 
o protozoário se multiplica no fígado e começa a atacar os glóbulos vermelhos (EWALD, 1994). O período de incubação dura 35 dias e o indivíduo infectado exibe os seguintes sintomas: dor de cabeça, calafrios, dores nas juntas e febre; sensações de frio se alternam com febre e sudação e os desconfortos podem retornar vários anos após a contaminação. A enfermidade pode atingir o cérebro (malaria cerebral) e dão surgimento a convulsões, aumento da pressão intra-craniana, coma e morte.

Os efeitos sociais da malária são consideráveis, pois ela interfere na economia e no funcionamento pleno das instituições. Um dos contos do mineiro J. Guimarães Rosa (Sarapalha, da coletânea Sagarana, 1946) descreve a situação dos moradores de um vilarejo fictício que se transformara num santuário de mosquitos anofelinos. $\mathrm{O}$ escritor conhece bem o assunto, pois era médico e nascera numa região flagelada pela malária. A conversa entre os personagens é marcada por ranger de dentes e calafrios que se alternam com intensa sudorese, pois suas entranhas eram habitadas por bichinhos malvados que, em dias alternados, liberavam seus enxames na corrente sanguiínea. A leitura do conto Sarapalha permite até suspeitar que os personagens eram vítimas do Plasmodium falciparum, o agente patogênico que provoca a forma mais grave da enfermidade. Os membros da expedição Langsdorff também foram atacados pelos mosquitos anofelinos, como descreveu Hercule Florence:

O Sr. Langsdorff e Rubtsov continuavam muito doentes. Estavam tão fracos que não conseguiam sair das redes e perderam totalmente o apetite. Diariamente, a mesma hora, voltavam os calafrios, procedidos por ataques de febre extremamente fortes que os obrigavam a emitir gemidos sucessivos e a contraírem-se convulsivamente, fazendo estremecer as árvores, nas quais estavam penduradas as redes, os mosquiteiros e as cobertas... Os sofrimentos eram acrescidos pelas feridas de picadas de insetos (In: KOMISSAROV, 1992; p. 123).

Alguns estudos apontam que o Plasmodium falciparum se tornou importante agente patogênico cerca de 10.000 anos atrás, provavelmente na África (EWALD, 1994; PACKARD, 2007). A malaria foi um dos fatores que dificultou a colonização do interior do Brasil; ela também ceifou muitas vidas durante a Guerra Civil nos EUA (1861-65), construção do Canal do Panamá (1903-14) e limitou a colonização européia do continente africano (ver PACKARD, 2007). A luta para a erradicação da malária tem sido marcada por insucessos. 
Por muito tempo perdurou a idéia que ela fosse resultante das "emanações pútridas" dos pântanos e do solo contaminado. Com efeito, o nome da enfermidade é de origem italiana (mala aria, ar ruim), mas os colonizadores portugueses usavam palavras mais elucidativas para descrevê-la: maleita (Latim: maledicta ou febris maledicta, febre maldita) ou sezão (Latim: aglutinação simplificada de accessione, acesso de febre intermitente, e sazão, estação do ano).

O cenário desalentador começou a melhorar a partir de 1897, ocasião em que Sir Ronald Ross (1857-1932), médico e epidemiologista inglês, descobre que a enfermidade é transmitida pelos mosquitos anofelinos, os quais proliferavam nos banhados, rios e lagoas da Índia. A descoberta do ciclo evolutivo do agente transmissor permitiu o combate à enfermidade e Sir Ronald foi agraciado com o prêmio Nobel em Fisiologia ou Medicina (1902). Os cientistas acreditavam que as fontes de água paradas eram os únicos reservatórios dos mosquitos anofelinos, mas Adolfo Lutz (1855-1940) notou que os operários da estrada de ferro Santos-SP também padeciam de malária (1903). Era algo inusitado, pois os ferroviários trabalhavam em plena floresta pluvial na Serra do Cubatão, local bem drenado. Lutz busca informações nos resultados das pesquisas de Fritz Müller (1822-87) e fica espantado ao constatar que as águas acumuladas pelas bromélias eram reservatórios naturais de larvas de mosquitos anofelinos (CHAGAS, 1940; MARTINS, 1955; REITZ. 1983, 1986).

O combate à malária era bastante precário nos estados do Norte e Centro-Oeste, em razão das condições climáticas favoráveis à proliferação do mosquito Anopheles e enorme extensão territorial, mas o problema também existia na Santa (e bela) Catarina. Um programa de erradicação foi instalado na região e atingiu bons resultados devido ao espírito clarividente das autoridades sanitárias e os esforços da equipe de especialistas. A vegetação catarinense é rica em espécies bromeliáceas, plantas que chegam a acumular até 4 litros de água entre as bases de suas folhas e, portanto, são focos de atração para várias espécies de organismos, entre os quais uma grande variedade de insetos. Padre Raulino participou intensamente dessa luta, pois ele já era um respeitado especialista nessas plantas.

A malária atingia cerca de $30 \%$ do território catarinense e era um grave problema de saúde pública: as escolas fechavam, as fábricas interrompiam suas atividades e os serviços de saúde não davam conta do número crescente de indivíduos infectados. Alguns núcleos urbanos desapareceram, pois os moradores abandonavam suas casas e suas atividades em busca de cantos mais seguros; o fluxo migratório adensou as periferias das grandes cidades e teve impacto na atividade agropecuária. As cidades catarinenses estavam distantes da desoladora Sarapalha, o fictício vilarejo descrito por Guimarães Rosa, mas o problema estava se agravando. 
Padre Raulino conhecia bem o problema a ser enfrentado, pois desde criança que ele fora vítima da malária. Até no Seminário de Azambuja os episódios de infestações eram freqüentes e ele chegava a ter oito vezes por ano os terríveis acessos de febres. Atualmente, nossas terras são conhecidas por sua qualidade de vida, belas praias e povo saudável, mas nos anos seguintes à II Guerra Mundial o cenário era desalentador e completamente diferente do colorido dos dias atuais. Na década de 1950, a enfermidade chegava a atingir direta ou indiretamente cerca de 1 milhão de pessoas em Santa Catarina e, ao ser convidado a participar dos esforços para erradicação da doença, Padre Raulino encarou o convite como algo de interesse pessoal e um gesto em defesa de sua comunidade. Essas coisas facilmente caem no esquecimento, mas merecem ser examinadas com maior atenção.

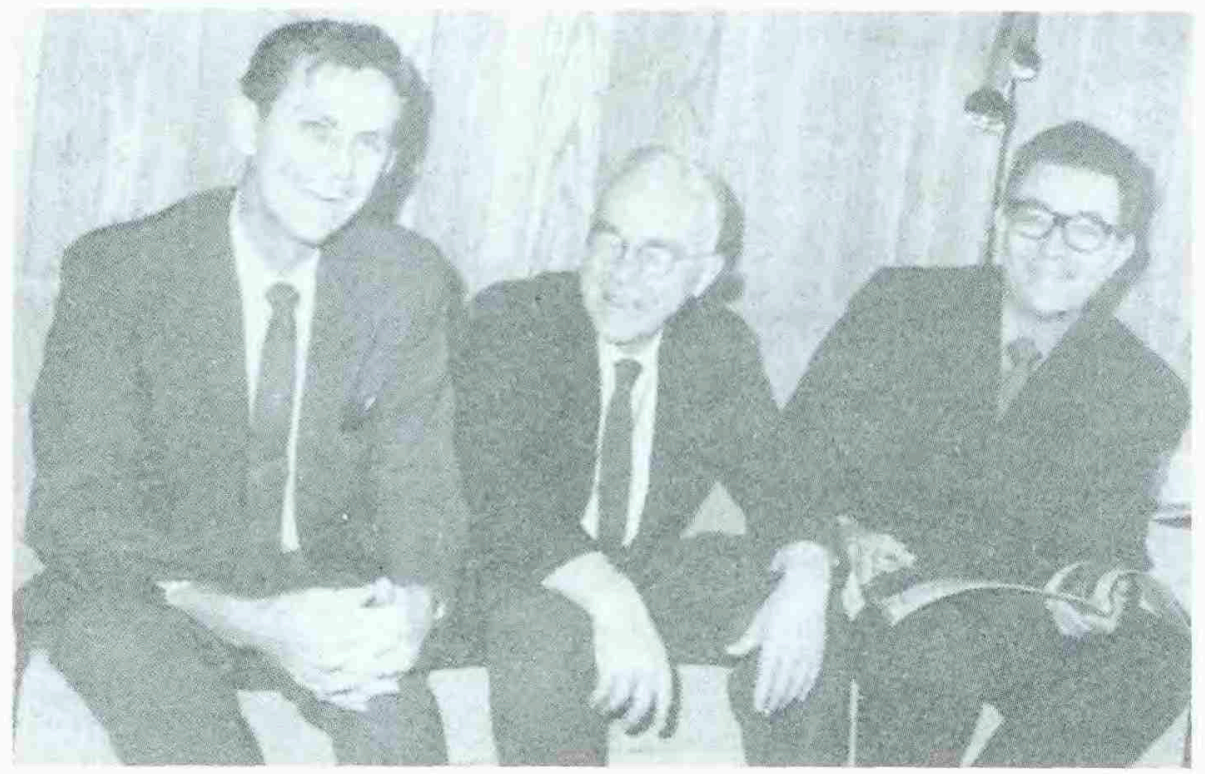

Figura 3

O encontro de botânicos na residência do Dr. Robert Jack Downs (Raleigh, Carolina do Norte/EUA). Da esquerda para a direita: Downs, Lyman B. Smith e Padre Raulino.

Desde as primeiras décadas do século 20 que o Brasil vinha obtendo bons resultados no controle das doenças endêmicas, graças aos esforços dos médicos sanitaristas que se reuniram em torno de Oswaldo Cruz. Esses avanços beneficiaram os países vizinhos e scholars insuspeitos apontam a enorme injustiça de nunca termos tido a satisfação de ver um cientista brasileiro agraciado com o prêmio Nobel em Fisiologia ou Medicina. Além do interesse em combater nossas próprias doenças, outro fator impulsionou a medicina sanitária no Brasil. 
Com efeito, no final da II Guerra Mundial, os EUA promoveram a conhecida política da "boa vizinhança" em sua área de influência, o que resultou em parcerias com governos para o combate das doenças tropicais, principalmente a malária.

O Brasil e EUA firmam, por meio do Instituto Oswaldo Cruz e Fundação Rockfeller, firmam um convênio dessa natureza e, ato contínuo, nossas autoridades solicitam à Washington o envio de um botânico especialista em bromélias. Os americanos recorrem ao Dr. Lyman B. Smith, respeitado botânico do Gray Herbarium (Departamento de Botânica da Harvard University), o qual responde imediatamente: no Seminário de Azambuja havia um especialista no assunto, sem necessidade de envio de algum americano ao Brasil. Ele estava se referindo ao Padre Raulino que atuava cerca de $2 \mathrm{~km}$ do local onde seria instalado o laboratório de malariologia.

O convite para participar dos esforços de erradicação da malaria ocorreu de modo inusitado e é o próprio Raulino quem descreve os detalhes. No dia 30 de Maio/1949, nos estágios iniciais do projeto, ele recebe a visita de Henrique Pimenta Veloso (1917-2003) e Firmino Torres de Castro, duas lideranças científicas que se encontravam à frente do programa. Eles traziam duas notícias importantes: Veloso e Castro informaram, para enorme contentamento do catarinense, que o Serviço de Nacional de Malária instalaria em Brusque/SC um laboratório de malariologia.

A notícia de instalação de um serviço de malariologia agradou ao Padre Raulino, mais ainda ao saber que ele fora convidado a participar diretamente dessa luta. Como foi mencionado anteriormente, ele e seus familiares haviam sofrido com a enfermidade e o seu coração pulsou mais forte ante a possibilidade de minimizar as desgraças vividas pelos membros de sua comunidade. Eram o sacerdote e o cientista que confabulavam entre si. O convite foi prontamente aceito e ele passou a ser incumbido de identificar as espécies bromeliáceas e outras que tinham relação com a malária. O trabalho foi incessante e rendeu bons frutos, mas as autoridades do projeto tiveram que se render a uma extravagância do Padre Raulino: ele exigiu que o seu envolvimento no projeto não fosse remunerado. Ele já detinha sólidos conhecimentos acerca das bromélias e muitos especialistas do exterior já o respeitavam, conforme podemos constatar nas circunstâncias que cercaram o convite para participar do projeto de erradicação da malária.

A luta contra a malária foi árdua e resultou num grave problema ambiental. Algumas regiões foram desmatadas e uma quantidade espantosa de plantas teve que ser incinerada. Conforme pode ser constatado nos depoimentos de Ademir Reis, as bromélias fazem parte de um grupo importante para determinação da biodiversidade, pois outras espécies de plantas e animais dependem de suas águas para a sobrevivência. Os esforços de erradicação da praga anofelina foram bem sucedidos, mas o preço foi elevado e deixou cicatrizes na alma do catarinense: 
Violenta agressão ecológica foi o preço para defender a saúde da população de Brusque, Blumenau, Joinville, Florianópolis e outras cidades importantes: por retirada manual ou por meio de desmatamento puro e simples, mais de 400 mil bromélias foram destruídas num trabalho que exigiu a reàlização de um dos maiores levantamentos fitossociológicos da América do Sul (REITZ, 1986; p. 50).

Os comentários revelam um misto de tristeza e sentimento de dever cumprido, o que é compreensível para um sacerdote-cientista. A malária era um gravíssimo problema de saúde pública e Padre Raulino fora convocado a prestar solidariedade à sua comunidade, em favor do ser humano. Atualmente, nós conhecemos melhor o problema e poderíamos até encontrar uma solução menos danosa ao ambiente, mas foi uma atitude racional e bastante corajosa. A participação do naturalista catarinense foi peça fundamental para a erradicação da malária em nosso estado, pois ele exibia três atributos importantes: os conhecimentos necessários, a motivação para se envolver no programa e, principalmente, a respeitabilidade de um sacerdote (ver o depoimento de Ademir Reis). Esses comentários também revelam a complexidade do relacionamento do homem com a natureza: ela é bela e gentil, mas também pode ser a origem de nossas desgraças.

\section{O legado de Raulino Reitz}

Padre Raulino trabalhou com muita gente e influenciou incontáveis pesquisadores. Um de seus colaboradores mais próximos foi o ex-seminarista Roberto Miguel Klein (1923-92). Os dois atuaram juntos em muitas atividades, como a administração do Herbário Barbosa Rodrigues e no programa de erradicação da malária em Santa Catarina. $\mathrm{O}$ reconhecimento internacional veio com o Prêmio Global 500 (5 de Julho/1990, na Cidade do México), distinção outorgada pela Organização das Nações Unidas às personalidades que se destacaram no mundo inteiro na luta em defesa do meio ambiente. Raulino foi membro de importantes agremiações científicas do Brasil e exterior e suas ações deram origem às reservas ambientais: Parque Estadual da Serra do Tabuleiro (1975), Parque Estadual da Serra Furada (1980), Reserva Biológica Estadual da Canela Preta (1980) e Reserva Biológica Estadual do Aguaí (1983). Ele foi diretor do Instituto de Pesquisas do Jardim Botânico do Rio de Janeiro (1971-75), honrando notáveis antecessores, como Frei Leandro do Sacramento (1778-1829) e João Barbosa Rodrigues (1842-1909). 


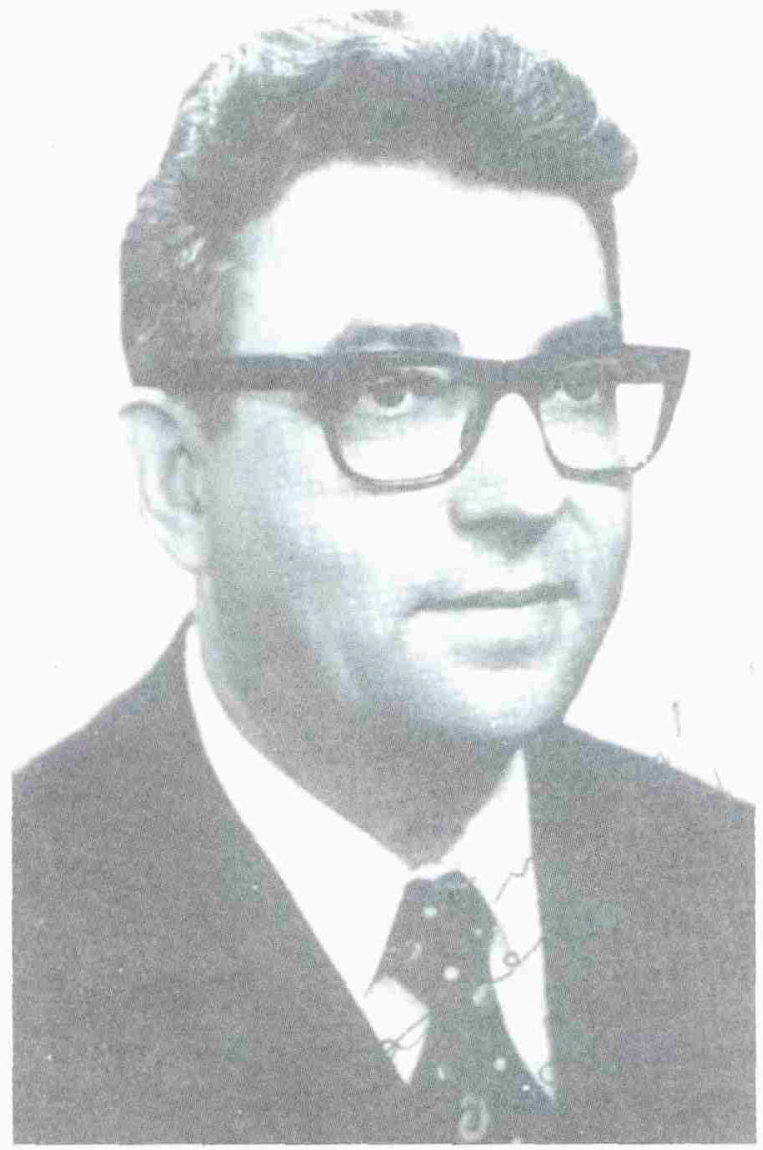

Figura 4

Padre Raulino Reitz.

O naturalista catarinense e seus seguidores praticamente descreveram toda a flora catarinense e os resultados dessas pesquisas são relevantes no cenário internacional. Além do conhecido herbário, ele também foi o idealizador de um periódico científico (Sellowia) que começou a circular a partir de 1949. O modo como surgiu o periódico revela os meandros da vida de um padre jesuíta. Antes de sua materialização, Raulino envia uma carta à D. Joaquim pedindo as bênçãos episcopais para o projeto (20 de Março/1948). Ele informa ao arcebispo que tinha algumas anotações e trabalhos inéditos sobre a flora catarinense, os quais foram obtidos nas horas de folgas e nos períodos de férias. Raulino também informou que fora estimulado por Balduíno Rambo, não existia um periódico dessa natureza em Santa Catarina e a Imprensa Oficial poderia executar os trabalhos gráficos. Tudo contribuía para o sucesso de Sellowia e o venerando D. Joaquim não se isentou de conceder as bênçãos ao projeto. 
Raulino Reitz era um idealista e tinha sonhos elevados: ele não era guiado pelo ser, o ter ou o poder, mas pelas ações. Essas são as palavras utilizadas por um amigo conterrâneo, o qual acrescenta outros aspectos da personalidade do naturalista catarinense:

\begin{abstract}
A imagem que Pe. Raulino deixa nos que o conheceram e admiraram é a de um homem simples, calmo, atencioso, satisfeito com a vida. Nunca buscou a fama, a badalação social. Não foi tocado pela vaidade humana, mesmo em meio a tanto reconhecimento pelo seu trabalho. Parecia não saber o que ele próprio significava para o mundo da ciência. Impressionava pelo número de projetos que conseguia tocar simultaneamente. Uma vida, por mais longa que seja é sempre muito curta para uma obra tão vasta. Foi um homem de método... (BESEN, 1992; pp. 77-8)
\end{abstract}

Ele foi um "homem de método". Isso é bastante esclarecedor, mas parece que mais dois fatores contribuíram para solidificar os traços de sua personalidade: o germanismo dos colonos que se instalaram em Santa Catarina e a formação religiosa dos padres jesuítas. Enquanto as famílias alemãs valorizavam o trabalho árduo e o relacionamento cerimonioso entre pais e filhos, o ensino nos seminários fortalecia esses elementos e adicionava outros, como o respeito hierárquico, a disciplina e a busca de um modo de vida ideal. De acordo com Padre Besen, são esses fatores que explicam a simpatia de seu conterrâneo pelo Integralismo de Plínio Salgado (1895-1975). O Sr. Nicolau Reitz, pai de Raulino, foi um integralista de primeira hora no município Antonio Carlos e foi até sepultado com a bandeira do partido. Os presentes ao sepultamento gritavam "Anaué" e ostentavam braçadeiras com a letra sigma.

O integralismo não teve muito significado no cenário nacional, mas foi influente no Sul do país, onde os traços da colonização alemã são marcantes. O movimento contava com as simpatias de vários setores da sociedade, mas ficou associado ao germanismo das colônias do Paraná, Santa Catarina e Rio Grande do Sul. Entretanto, muitos repressores do movimento tinham ascendência alemã, da mesma forma que entre os simpatizantes contavam alguns negros, açorianos e membros da Igreja Católica. A repressão em Santa Catarina foi liderada por Nereu Ramos (1888-1958) e foi razoavelmente violenta: muitos simpatizantes passaram longas temporadas na cadeia, túmulos com a letra sigma foram depredados e Plínio Salgado teve que buscar refúgio em Portugal. A simpatia dos colonos alemães pelo Integralismo parecia indicar mais o desejo de auto-afirmação dos grotões esquecidos pelo poder público - o governo só se fazia presente na hora de cobrar impostos! Um governo forte, 
eficiente e centralizador agradava aos olhos do Padre Raulino, mas a "fase Anauêe" foi algo efêmero e não deixou vestígios no seu legado intelectual e humanístico.

Padre Raulino foi um educador exemplar e suas pesquisas sobre as plantas e vegetação da região Sul servem como referência a muitos pesquisadores. O seu interesse pelas coisas e cultura catarinense o levou a escrever livros sobre os municípios de Santa Bárbara e Antonio Carlos, sem esquecer que ele fora membro do Instituto Histórico e Geográfico de Santa Catarina e da Academia Catarinense de Letras (não chegou a tomar posse) - ele foi eleito em II de Outubro/1990, mas durante uma homenagem na Câmara dos Vereadores de Itajaí/SC, ele sofre um infarto fulminante e em poucas horas é diagnosticada a sua morte (20 de Novembro/1990).

\section{Conclusão: “Antonio Carlos? Quem foi Antonio Carlos?”}

Durante uma conversa informal com alguns intelectuais catarinenses - a região do Alto Biguaçu tem vários filhos de boa linhagem -, todos eles demonstraram certa insatisfação com o pouco destaque dado à memória do ilustre conterrâneo, mais ainda em relação ao nome dado à sua terra natal. Antonio Carlos? Quem foi Antonio Carlos?, alguns desavisados perguntaram. Trata-se de uma improvisação que as antigas autoridades encontraram para designar a região do Alto Biguaçu' (ou Louro), que então seria separada do município Biguaçu. A falta de imaginação ou certa dose de sabujice deu origem ao atual nome do município, embora o mais adequado fosse recorrer à memória de algum filho ilustre da região para tal homenagem. Esses intelectuais informaram que a idéia não é nova e todos se apegaram ao nome do Padre Raulino. Um depoimento de Flavio José Cardozo, membro da Academia Catarinense de Letras, fornece mais detalhes sobre a curiosa origem do nome do município de Antonio Carlos:

Muitos pensam que o nome é uma homenagem ao catarinense Antonio Carlos Konder Reis. Pois não é. Esse Antonio Carlos não tem nenhuma ligação com o nosso estado e muito menos com a comunidade para a qual foi lembrado. Trata-se de Antonio Carlos Ribeiro de Andrada, político mineiro, expoente da Revolução de 30, e que já dá nome, em Minas, a um outro município. A honraria teve caráter simplesmente político. O povo não foi ouvido, ninguém perguntou por seu sentimento, cumpriuse apenas um decreto do general gaucho Ptolomeu de Assis Brasil, interventor federal em Santa Catarina, que mandava substituir Louro por Antonio Carlos (Diário Catarinense, 10 de Dezembro/1990). 
O referido personagem que emprestou o seu nome para o topônimo foi um governador mineiro que não tem a menor ligação com Santa Catarina, tampouco com a antiga comunidade do Louro. Isso deve ser enfatizado. Esses intelectuais foram unânimes em reconhecer que se trata de uma homenagem esdrúxula e imerecida. A mudança do nome é recomendável e os mineiros não ficariam aborrecidos com o gesto, até porque a sua memória já foi preservada no nome de um município em Minas Gerais. Trata-se de uma dupla inconveniência, é verdade. Em segundo lugar, a comunidade do Louro ganhou novo nome a partir de decisões tomadas dentro dos gabinetes oficiais, sem nenhuma participação dos moradores. Até os moradores mais antigos se sentem confusos ou não têm a mínima idéia sobre quem é o verdadeiro Antonio Carlos, personagem da vida política que perdeu importância com os desdobramentos da história.

Os moradores designavam a região de Louro ou Alto Biguaçu e até surgiu alguma movimentação para tomar oficial o nome "Coração de Jesus", mas preponderou a esdrúxula homenagem ao governador mineiro. Na primeira reunião oficial da Câmara dos Vereadores (30 de Julho/1963), quando muitos moradores sequer sabiam que o rincão tinha um novo e inusitado nome, surgiu a proposta de anular a nomenclatura oficial, em favor de "Reitzburgo". A idéia era justa e correta, pois tinha como objetivo a valorização da memória de João Adão Reitz, o pioneiro da colonização do Vale do rio Rachadel, mas o viés aliancista dos vereadores não fez prosperar a mudança. Infelizmente, o nome não tinha boa sonoridade e o sufixo era estranho aos ouvidos.

Num texto acadêmico não existe espaço para maiores alongamentos sobre tais assuntos, mas é inevitável que em algum momento os habitantes do Alto Biguaçu tenham que lidar de modo satisfatório com a memória de seus filhos ilustres, como o Padre Raulino e a parteira Maria Platten. A mudança do topônimo também se justifica por mais dois motivos: é importante que os antigos habitantes da região se assenhoreiem e sua história ou porque é sempre salutar alguma dose de rebeldia em relação às sabujices perpetradas nos gabinete oficiais, às custas do orgulho de uma comunidade laboriosa.

\section{Agradecimentos}

A versão preliminar deste texto foi examinada pelos colegas Arno Blass, Flávio José Cardoso, José Baus e Salim Miguel, o que permitiu a eliminação de erros e adições de valiosas informações. Porventura o leitor detecte algumas falhas no texto, elas devem ser atribuídas ao direcionamento acadêmico do autor. A conversa com o Sr. Natalício Antonio Custódio, Seu Ticula, foi intermediada pelo neto Jones da Silva Custódio, aluno do curso de Letras da UFSC, e Luiz Carlos Cardoso, secretário da Revista de Ciências Humanas e filho de um amigo de Ticula, o Sargento Bala. 


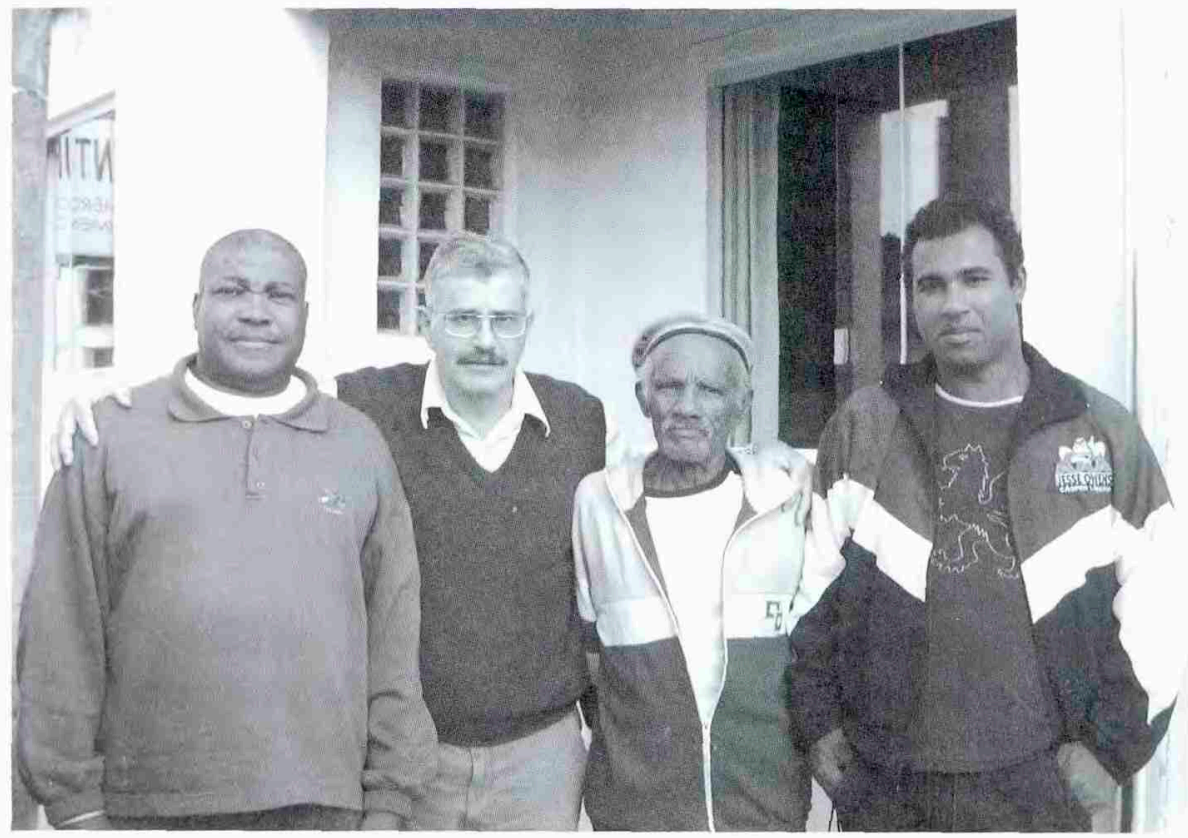

Figura 5

O encontro com Natalício Antonio Custodio, Seu Ticula, um dos moradores mais antigos da antiga Comunidade do Louro (Município de Antonio Carlos/SC). Da esquerda para a direita: Luiz Carlos Cardoso, filho de seu amigo e secretário de $\mathrm{RCH}$, o editor da revista, Ticula e o seu neto Jones da Silva Custodio.

\section{Referências bibliográficas}

BEDIAGA, B. Conciliar o útil ao agradável e fazer ciência: Jardim Botânico do Rio de Janeiro - 1808 a 1860. História, Ciência, Saúde - Manguinhos, 14(4): 1131-57, 2007.

BERNARDES, Z.H.D. Cônego Dr. Raulino Reitz - "O padre dos gravátas". Sellowia, 45-48: 5-12, 1996.

BESEN, J.A. Padre Raulino Reitz - para recordar. In: R. Reitz. Santa Barbara - primeiro núcleo da colonização alemã em Santa Catarina. Pp. 68-78. Florianópolis: EDUFSC, 1992.

CABRAL, O.R. Nossa Senhora do Desterro. Vol. II. Florianópolis: UFSC, 1972.

CARDOSO, J.L. From natural history to political economy: the enlightened mission of Domenico Vandelli in late eighteenth-century Portugal. Studies in History and Philosophy of Science, 34: 781-803, 2003. 
CHAGAS, C. Adolpho Lutz. In: L. Ribeiro (Org.). Medicina no Brasil. Pp. 129-36. Rio de Janeiro: Imprensa Nacional, 1940.

DE AZEVEDO, F. Brazilian culture. Nova York: MacMillan Co., 1950.

DE CARVALHO, R. História natural de Portugal no século XVIII. Lisboa: Ministério da Educação, 1987.

DE MORRETES, B.L. Felix Rawitscher. Estudos Avançados, 8(22): 205-08, 1994.

DESCHAMPS, F.C. \& SALERNO, A.R. Roberto Miguel Klein (1923-1992). In: V.M. de Carvalho \& V.R. da Costa (Coords.). Cientistas do Brasil. Pp. 619-29. São Paulo: SBPC e CNPq, 1998.

DE SOUZA, V.S. Arthur Neiva e a "questão nacional" nos anos 1910 e 1920. História, Ciências, Saúde - Manguinhos, 16(Supl. 1): 249-64, 2009.

DOS SANTOS, N.P.; PINTO, A.C. \& DE ALENCASTRO, R.B. Theodoro Peckolt: naturalista e farmacêutico do Brasil Imperial. Química Nova, 2I(5): 666-70, 1998.

EWALD, P.W. Evolution of infectious disease. Oxford: Oxford University, 1994.

FERRI, M.G. A botânica no Brasil. In: F. de Azevedo (Org.). As ciências no Brasil. Vol. 2, pp. 175-23I. São Paulo: Melhoramentos, 1955.

FERRI, M.G. História da botânica no Brasil. In: M.G. Ferri \& S. Motoyama (Coords.). História das ciências no Brasil. Pp. 33-88. São Paulo: EDUSP, EPU e CNPq, 1979.

GUERRA, R.F. Oswaldo Rodrigues Cabral: notas sobre a trajetória de vida de um intelectual brilhante. Revista de Ciências Humanas, 42(1-2): 9-60, 2008.

GURIB-FAKIM, A. Medicinal plants: traditions of yesterday and drugs tomorrow. Molecular Aspects of Medicine, 27: 1-93, 2006.

KOMISSAROV, B. Da Sibéria à Amazônia - a vida de Langsdorff. Brasília: Edições Langsdorff, 1992.

LEINZ, V. A geologia e a paleontologia no Brasil. In: F. de Azevedo (Org.). As ciências no Brasil. Vol. 2, pp. 275-95. São Paulo: Melhoramentos, 1955.

MARQUES, A.J. \& FILGUEIRAS, C.A.L. O químico e naturalista luso-brasileiro Alexandre Antonio Vandelli. Química Nova, 32(9): 2492-500, 2009.

MARTINS, T. A biologia no Brasil. In: F. de Azevedo (Org.). As ciências no Brasil. Vol. 2, pp. 233-300. Rio de Janeiro, Editora UFRJ, 1955. 
NEIVA, A. Esboço histórico sobre a botânica e zoologia no Brasil. São Paulo: Sociedade Imprensa Paulistana, 1929.

OSTOS, J.M. Estudio preliminary. In: F.L. de Gómara. Historia de la conquista de México. Pp. ix-lx. Mexico, DF: Editorial Porruá, 2006.

PACKARD, R.M. The making of a tropical disease: a short history of malaria. Nova York: The Johns Hopkins University Press, 2007.

RAMÓN Y CAJAL, S. Recollections of my life. Cambridge: MIT Press, 1991.

REIS, A. Herbário Barbosa Rodrigues - 50 anos de atividades (1942-1992). Sellowia, 42-44: 5-24, 1992.

REIS, M.J. \& FOSSARI, T.D. Arqueologia e preservação do patrimônio cultural: a contribuição do Pe. João Alfredo Rohr. Cadernos do CEOM, 22: 265-93, 2009.

REITZ, R. Bromeliáceas e a malária-bromélia endêmica. Itajaí: Flora Ilustrada Catarinense, 1983.

REITZ, R. Bromélias na trama da malária. Ciência Hoje, 4(21): 50-7, 1986.

REITZ, R. Alto Biguaçu. Florianópolis: Editora Lunardelli e EDUFSC, 1988.

REITZ, R. Santa Bárbara, primeiro núcleo da colonização alemã em Santa Catarina. Florianópolis: EDUFSC, 1992.

SÁ, M.G. O botânico e o mecenas: João Barbosa Rodrigues e a ciência no Brasil na segunda metade do século XIX. História, Ciências, Salide - Manguinhos, VIII (Supl): 899-924, 2001.

SANTOS FILHO, L. A história da medicina no Brasil. São Paulo: Editora Brasiliense, 1947.

TRAVASSOS, L. A atuação científica de Arthur Neiva no campo da biologia. Memórias do Instituto Oswaldo Cruz, 40(1): I-VI, 1944.

VANZOLINI, P.E. Naturalistas e viajantes no Brasil. Revista USP, 30: 190-238, 1996.

VON MARTIUS, K.F.P. Natureza, doenças, medicina e remédios dos índios brasileiros. São Paulo: Companhia Editora Nacional, 1939.

VON SPIX, J.B. \& VON MARTIUS, C.F.P. Viagem pelo Brasil. Volume terceiro. Rio de Janeiro: Imprensa Nacional, 1938.

WILSON, E.O. Naturalist. Londres: Allen Lane \& The Pinguin Press, 1994. 


\section{Para não esquecer Padre Raulino}

Ademir Reis

Ele é Professor-Titular lotado no Departamento de Biologia da Universidade Federal de Santa Catarina, onde iniciou as atividades em 1 de Março/ 1978. A sua graduação em Biologia foi obtida na própria UFSC, mas os títulos de Mestre e Doutor em Botânica foram obtidos na UNICAMP. A sua carreira acadêmica teve início ainda no curso Ginasial, ocasião em que Padre Raulino ministrava aulas de ciências no Seminário Menor de Azambuja e desde os 13 anos de idade que Reis passou a the auxiliar nas coletas de plantas e correção de provas - ele era uma espécie de monitor e auxiliar de pesquisa. Ao assumir a direção do Jardim Botânico do Rio de Janeiro (1971-75), Padre Raulino solicitou que Reis o substituísse nas aulas de ciências no Seminário de Azambuja; ele foi professor no curso Ginasial até 1973, ocasião em que interrompe as atividades para iniciar a formação em Teologia. Reis também é formado em Filosofia e tudo indicava que iria seguir carreira eclesiástica mais uma pedra preciosa no cesto de D. Joaquim! -, mas uma crise existencial se instalou em seu coração e ele decidiu seguir outros rumos. O curso de Biologia é concluído em pouco tempo na Fundação Universitária da Região de Blumenau (FURB, 1975), pois muitas disciplinas ele havia concluído nos cursos de Filosofia e Teologia. A atuação no Herbário Barbosa Rodrigues vinha desde os tempos colegiais e se intensificou com os passamentos de duas lideranças científicas, Raulino (20 de Novembro/1990) e de Roberto M. Klein (13 de Novembro/1992). Ademir Reis não teve sequer tempo para outra crise existencial, pois teve que assumir imediatamente a direção do herbário. Esses três personagens estão relacionados ao desenvolvimento da Botânica no Estado de Santa Catarina, mas a importância escapa às nossas fronteiras. Com efeito, Raulino Reitz e Roberto Klein são agraciados com uma importante distinção da Organização das Nações Unidas (Premio Global 500, 1990) e Reis foi um dos homenageados pelo Governo Federal com a Ordem do Mérito Científico (Março/2010), como reconhecimento aos brasileiros que se destacaram em vários campos do conhecimento.

RCH - Como v. conheceu o Padre Raulino?

Reis - Eu tive o privilégio de conhecê-lo quando tinha 13 anos de idade, ocasião em que eu me encontrava no Seminário de Azambuja. Ele foi o meu professor de ciências no curso Ginasial e era o responsável pelas disciplinas Astronomia, Botânica e ciências de modo geral. Padre Raulino entusiasmava os alunos com suas aulas e foi através dele que eu me interessei pelas plantas; ele foi o meu guia nos primeiros passos da vida acadêmica e até hoje "continua" comigo. 
Eu o acompanhava em seus estudos de campo, recebia presentes (livros sobre orquídeas) e era orientado em minhas primeiras coletas. Isso vinha desde os tempos do curso Ginasial e até hoje Padre Raulino é o meu orientador.

RCH - V. teve um longo e intenso relacionamento com o "padre dos gravatás". Descreva seus traços de personalidade.

Reis - Padre Raulino era uma pessoa extremamente disciplinada e organiza$\mathrm{da}$; ele era bastante detalhista e gostava de planejar bem as viagens de estudo. mas a rigidez e o rigor eram para consigo próprio. Fora desse contexto, ele era uma pessoa jovial, bem humorada e entendia perfeitamente as limitações de cada um. É importante também ressaltar que ele era um homem idealista e a ciência era a paixão de sua vida. A cada viagem que fazia, ele julgava importante mostrar aos alunos as novidades; ministrava palestras, organizava encontros e seminários para compartilhar os novos conhecimentos. Nós tínhamos acesso a um mundo de novidades, pois vivíamos fechados no seminário e estávamos mais envolvidos com questões religiosas, sem contar que muitos de nós éramos oriundos de famílias do interior, sem contato com as coisas das ciências. Padre Raulino estimulava as vocações cientificas e ampliava nossos horizontes. O ensino religioso no seminário não era nem um pouco descuidado, mas a parte secular ficava aos seus encargos. Ele escutava rotineiramente a Voz das Américas, acompanhava com vívido interesse a visita do homem à Lua e buscava se inteirar dos avanços no campo da Astronomia. Padre Raulino estava sempre em busca de informações e sempre encontrava um jeito de inserir as novidades científicas em suas aulas; ele era um grande divulgador da ciência.

$\mathbf{R C H}$ - Comente a formação inicial e principais influências que moldaram a personalidade do Padre Raulino.

Reis - Ele era um homem inteiramente devotado à ciência. Ele era oriundo de uma escola de padres jesuítas, os quais se notabilizaram como grandes cientistas, principalmente no campo das ciências naturais. A sua formação inicial ocorreu no Rio Grande do Sul e os padres tinham uma excelente formação científi$\mathrm{ca}$, os quais se destacaram como cientistas. Eu cito como exemplos os padres Balduíno Rambo (1905-61) e João Alfredo Rohr (1908-84), excelentes educadores e pesquisadores respeitados na comunidade científica. Outra pessoa que contribuiu bastante para o seu desenvolvimento acadêmico foi Dom Joaquim Domingues de Oliveira (1878-1967), arcebispo metropolitano da época. Ele respeitava muito os trabalhos do Padre Raulino e o cercava de privilégios, como agenda de compromisso mais flexível e possibilidade de escolha do local para o desenvolvimento de suas funções sacerdotais; D. Joaquim entendia perfeitamente a importância das pesquisas do Padre Raulino, pois seus conhecimentos enriqueciam a formação dos futuros sacerdotes; o arcebispo deixava-o livre para dar prosseguimento às suas viagens de estudos e pesquisas de campo. 
Os sermões do Padre Raulino eram diferentes, pois exploravam a relação do homem com a natureza; isso é corriqueiro nos tempos atuais, mas era uma novidade na época. Ele era muito culto, ouvia estações de rádio estrangeiras, era assinante de revistas científicas e os seminaristas tinham, através de suas aulas, o acesso a um conhecimento bastante atualizado. É verdade que alguns padres do seminário não aceitavam suas idéias, principalmente no que diz respeito à teoria sobre origem da vida, mas Padre Raulino era respeitado por todos e seus alunos assistiam empolgados às suas aulas. Ele desempenhava um importante papel na formação dos jovens seminaristas, pois era a única referência científica dentro do Seminário de Azambuja.

RCH - Como os resultados das viagens eram incorporados nas aulas?

Reis - Padre Raulino viajava muito e, após o retorno, ele realizava uma apresentação formal acerca das novidades que ele tivera acesso. Os assuntos eram variados, não necessariamente no campo da Botânica. Ele ministrava palestras sobre os avanços da Química nos EUA e na Europa, discutia as recentes teorias cosmológicas, descobertas de novas espécies da fauna e assim por diante. Os alunos ficavam empolgados com as apresentações. Padre Raulino se preocupava com a formação dos alunos e era quase a nossa única referência secular. Os demais padres cuidavam da formação religiosa, mas ele oferecia outro tipo de conhecimento e ampliava os nossos horizontes. Ele foi importante para várias gerações que passaram pelo seminário, os quais hoje atuam como políticos, juízes, professores universitários e várias autoridades que atualmente exercem influência no cenário catarinense. Todos eles passaram pelas mãos do Padre Raulino.

RCH - Como ele se relacionava com os demais padres do seminário?

Reis - Eu pude observar o seu isolamento dentro do Seminário de Azambuja, pois seus colegas estavam mais voltados para as discussões religiosas e não acompanhavam seus interesses pelo conhecimento científico. O relacionamento era cordial e respeitoso, mas não havia uma amizade genuína com seus contemporâneos. Padre Raulino contava com amigos influentes na Igreja Católica, mas ele era mais um cientista que padre propriamente dito. Ele trabalhava até $18 \mathrm{~h}$ por dia, dormia pouco e todo o tempo livre era dedicado aos estudos de Botânica, a sua paixão. Quando realizava uma descoberta, ele era inteiramente absorvido pelo trabalho; enquanto não findasse a descrição ou alguma tarefa relacionada, ele não descansava. Padre Raulino era firme e obstinado em seu trabalho, publicava livros e artigos a cada ano, viajava muito e não se descuidava de suas funções no Seminário de Azambuja. Eu o ajudei muito a corrigir os trabalhos dos alunos e pude perceber a sua enorme dedicação a tais tarefas. $O$ trabalho era monótono e extenuante e, certa ocasião, após um longo e extenuante período de trabalho, eu tive que the implorar alguns momentos de repouso. 
RCH - E a sua importância no cenário científico?

Reis - Padre Raulino publicou vários livros e foi o criador do Herbário Barbosa Rodrigues, feito que o tornou conhecido no mundo inteiro; suas publicações servem como referência aos especialistas do mundo inteiro e muitas foram traduzidas para outros idiomas, entre os quais o russo e o japonês. Ele descobriu mais de 500 espécies de bromélias e seu nome foi emprestado para designar cerca de 60 espécies e três gêneros: Raulinoa Cowan, Reitzia Swallen e Raulinoreitzia King e Robinson, plantas da família das laranjeiras e das gramíneas. A sua paixão era a Botânica, mas Raulino também atuou como educador das ciências em geral. Ele ministrava aulas de Astronomia, Química e estava muito interessado nos avanços tecnológicos, como o pouso da nave Apollo 11 na Lua (20 de Julho/1969). Um de seus passatempos favoritos eram as observações astronômicas. Em noites e madrugadas favoráveis, Padre Raulino levava os alunos para contemplar as estrelas e constelações ou realizar registros sobre a passagem de cometas. Era o seu hobby. Essas atividades não faziam parte da grade curricular, mas os alunos participavam espontaneamente e se deixavam contaminar pelo entusiasmo do Padre Raulino. Esse era o seu jeito de trabalhar.

RCH - Como germinou o seu interesse pelas plantas?

Reis - O seu interesse pela Botânica foi resultante da influência de João Evangelista Rick (1869-1946) e Pio Buck (1883-1972), padres jesuítas que ensinavam no Seminário de Porto Alegre/RS. Este último tinha por hábito levar chás para os presidiários, ao mesmo tempo em que estudava as plantas e elaborava novas fórmulas do produto; Padre Buck era bastante conhecido por seu trabalho junto aos presidiários e associava os interesses pela Botânica com a missão religiosa. O seminarista Raulino fora convocado lhe prestar auxílio nessas atividades, ocasião em que ele passa a se interessar pela Botânica e adquire experiência na herborização de plantas. A sua coleção de bromélias surge quase concomitantemente com a de Lyman Bradford Smith (1904-97), botânico americano que se tornou amigo próximo de Raulino. Os dois mantinham correspondência regular, um mandava livros para o outro e espontaneamente emerge uma sólida amizade entre os dois. Após algum tempo, Padre Raulino se dirige aos EUA, onde passa dois anos estagiando no herbário do Smithsonian Institution. Apesar desses contatos e de suas amizades com notáveis cientistas, Padre Raulino não teve uma formação acadêmica regular, pois simplesmente não existiam escolas e faculdades relacionadas ao curso de Botânica; os livros sobre o assunto eram raríssimos e, com efeito, a cada viagem que realizava, ele vinha com fotocópias de livros antigos e mostravam aos alunos interessados. Padre Raulino foi um autodidata e com muito esforço se especializou em Botânica. 
RCH - Como surgiu o Herbário Barbosa Rodrigues?

Reis - Atualmente, o incentivo à pesquisa no Brasil é bastante precário, mas era pior na época em que Raulino inicia as suas pesquisas. O herbário foi criado basicamente com os recursos orçamentários do Smithsonian Institution. A nossa coleção é duplicada naquela instituição, pois Raulino enviava documentos, informações e amostras aos EUA e, em contrapartida, recebia os recursos necessários à pesquisa e construção do Herbário Barbosa Rodrigues. O convênio foi importante para o desenvolvimento da Botânica em Santa Catarina, mas o procedimento não seria possível nos tempos atuais. O nome do herbário foi uma fórmula que Raulino encontrou para homenagear o primeiro botânico brasileiro, o carioca João Barbosa Rodrigues (1842-1909).

RCH - Como era o seu relacionamento com a teoria da evolução das espécies? Reis - Padre Raulino era um cientista sob todos os aspectos, mais que um religioso propriamente dito. Entretanto, eu nunca notei nele alguma crise de natureza espiritual, pois ele sabia conciliar o interesse científico com suas responsabilidades religiosas. Ele conhecia e era adepto da teoria da seleção natural, postulada pelo inglês Charles Darwin. É importante ressaltar que ele também ajudou a preservar a memória de Fritz Müller (1822-97), o naturalista que despendera boa parte de sua vida em Santa Catarina e que dera contribuições para o desenvolvimento da Botânica; como sabemos, Müller era um ardoroso defensor da teoria postulada pelo naturalista inglês e chegou a escrever um livro em defesa de suas idéias (Für Darwin, 1864). Padre Raulino resgatou cartas e documentos que se encontravam espalhadas na Alemanha, o que auxiliou na preservação da memória de Müller. Padre Raulino contestava muitas postulações da Igreja Católica, principalmente no que diz respeito sobre a origem da vida; até hoje muitos religiosos não aceitam as idéias de Darwin, mas a instalação do Concílio Vaticano II (1962-65) minimizou bastante o conflito entre ciência e religião. Ainda no Seminário de Azambuja, Padre Raulino tinha essas questões bem delineadas na cabeça e era um defensor da teoria da seleção natural.

RCH - Os alunos gostavam dele?

Reis - Padre Raulino trazia coisas novas e diferentes para o seminário. Ele era simpático e espirituoso, mas não se descuidava da qualidade do ensino; os alunos gostavam muito de suas aulas e eu nunca soube de algum que tivesse sido punido por ele. Nos feriados e finais de semana ele se dedicava integralmente à Botânica.

RCH - Do ponto de vista metodológico, qual foi a contribuição do Padre Raulino? Reis - Padre Raulino não estava envolvido diretamente com alguma universidade e, portanto, não se preocupava em formar mestres ou doutores, 
mas ele criou o Herbário Barbosa Rodrigues e, posteriormente, a revista Sellowia. Esses dois empreendimentos foram relevantes para os avanços das ciências naturais em nosso estado. Qualquer especialista que resolva estudar botânica ou ecologia de modo geral, terá que se deparar com as contribuições do Padre Raulino. Ele fez um levantamento de praticamente toda a flora de Santa Catarina e todos os especialistas da América do Sul estudam a sua obra. Além do conhecimento científico propriamente dito, a sua contribuição metodológica é importante, pois os procedimentos que ele adotou para realizar as coletas foram inéditos. Ele dividiu o estado de Santa Catarina em 180 áreas e coletou amostras durante os 12 meses do ano; essas áreas não foram escolhidas ao acaso, pois a escolha obedeceu à tipologia e ao estado de preservação ambiental. Atualmente, os especialistas adotam tais procedimentos, mas a obra do Padre Raulino é diferenciada, do ponto de vista das descobertas científicas e inovação metodológica.

RCH - Qual era o seu entendimento acerca do conhecimento popular? Reis - O uso racional e inteligente dos conhecimentos dos habitantes das regiões visitadas foi outra contribuição importante do Padre Raulino. Ele sempre se fazia acompanhar pelos colonos e mateiros, pois eram essas pessoas que melhor conheciam as espécies nativas; eles conheciam o nome popular das plantas, sabiam onde elas eram mais abundantes e forneciam informações sobre as fases de floração e utilidade das plantas. Muitas dessas informações não se encontravam nos livros. Padre Raulino valorizava muito o conhecimento etno-botânico, pois sempre dizia: "Não vá ao campo sozinho! O pesquisador não sabe o tanto que o mateiro sabe!". Muitos livros e artigos científicos apontam a importância do conhecimento popular, mas Padre Raulino já estava bem à frente do tempo. Eu acho que o conhecimento etno-botânico foi uma das coisas mais importantes de sua obra.

$\mathbf{R C H}$ - Como ele contornava as dificuldades orçamentárias?

Reis - Além dos convênios com instituições da Europa e EUA, Padre Raulino era engenhoso diante da falta de recursos orçamentários. Ele sempre buscava conciliar interesses variados, tendo em mente melhores condições para o prosseguimento de suas pesquisas. No momento em que identificava uma nova espécie de planta, ele classificava a espécie com o nome de um governador ou de uma pessoa influente da comunidade. Era dessa forma que ele conseguia fortalecer a equipe de pesquisa e consolidação do herbário. As dificuldades orçamentárias sempre foi um problema para as pesquisas de campo, mas Padre Raulino usava eficazmente a inteligência para obtenção de financiamentos. 
RCH - Como foi o envolvimento do Padre Raulino na campanha de erradicação da malária em Santa Catarina?

Reis - Ao se envolver com os esforços da erradicação da malária, a campanha ganha novos rumos. O problema era grave em Santa Catarina, pois as fábricas interrompiam a produção, escolas não funcionavam e os doentes congestionavam os precários serviços de saúde. Era um problema muito grave. O litoral catarinense e as colônias alemãs instaladas em Blumenau, Brusque, Laguna e Itajaí padeciam com a malária, como ocorria nos demais estados da federação. A campanha de erradicação da malária teve início no Rio de Janeiro; os técnicos drenavam banhados e eliminavam possíveis focos de mosquitos transmissores da enfermidade, mas os resultados eram insatisfatórios e a malária continuava a interferir negativamente no funcionamento das instituições. Liderados por Henrique Pimenta Veloso (1917-2003), os pesquisadores começaram a estudar o ciclo de desenvolvimento dos mosquitos anofelinos e se depararam com um problema interessante: os estados do Sul do país são mais frios que os demais, mas isso não impedia a proliferação dos mosquitos. Foi descoberto que as bromélias retêm uma boa quantidade das águas das chuvas e a temperatura entre as folhagens é cerca de 3 a $4^{\circ} \mathrm{C}$ graus acima das águas dos banhados. $\mathrm{O}$ ambiente era favorável à proliferação de várias espécies de insetos, entre os quais os mosquitos transmissores da malária. Os pesquisadores entram em contato com Lyman B. Smith, a maior autoridade no assunto e considerado o "pai das bromélias", e solicitam ajuda para resolver o problema. Ele informa ao Governo Brasileiro que o melhor especialista nesse assunto era Raulino Reitz, que vivia no Seminário de Azambuja, cerca de $2 \mathrm{Km}$ do local onde seria instalado o Serviço de Malariologia. Ele é convidado a somar esforços na luta para a erradicação da malária e a sua aceitação promove novos direcionamentos ao programa. Junto com Veloso e Roberto Miguel Klein (1923-92), ele se torna o grande ator social nessa empreitada. É importante ressaltar que, além dos conhecimentos científicos e paixão naturalista, Raulino era um padre bastante respeitado pela comunidade; as pessoas aceitavam facilmente as suas recomendações, tomavam os remédios e permitiam as coletas de amostras de sangue. Todos conheciam o Padre Raulino e seus conhecimentos e respeitabilidade de um sacerdote contribuíram para o sucesso do programa de erradicação da malária em Santa Catarina.

RCH - Qual é a importância das bromélias para o ecossistema?

Reis - É enorme. Antes dos estudos sistemáticos sobre essas plantas, a importância era completamente ignorada e muitos associavam a sua presença com doenças e proliferação de mosquitos. As bromélias pertencem a um grupo chave para determinação da biodiversidade, pois as águas retidas entre 
suas folhagens servem de ambiente para várias espécies de insetos, anfíbios, cobras, pássaros e crustáceos. É espantoso o número de espécies que dependem das bromélias para sobrevivência e, com efeito, em certos locais, existem mais espécies de bromélias que de árvores. Com efeito, o número de bromélias numa região freqüentemente é utilizado como parâmetro para os estudos sobre a biodiversidade. Não é necessário muito exercício da imaginação para perceber a importância de um reservatório de água aquecida no topo de uma árvore. 